\title{
Hydrochemical Characterisation of High-Fluoride Groundwater and Development of a Conceptual Groundwater Flow Model Using a Combined Hydrogeological and Hydrochemical Approach on an Active Volcano: Mount Meru, Northern Tanzania
}

\author{
George Bennett ${ }^{1,2, *(D)}$, Jill Van Reybrouck ${ }^{1}$, Ceven Shemsanga ${ }^{3}$, Mary Kisaka ${ }^{3,4}$, Ines Tomašek ${ }^{4,5,6,7}$, \\ Karen Fontijn ${ }^{8}$ (D), Matthieu Kervyn ${ }^{4}$ and Kristine Walraevens ${ }^{1}$ (D)
}

check for

updates

Citation: Bennett, G.; Van

Reybrouck, J.; Shemsanga, C.; Kisaka,

M.; Tomašek, I.; Fontijn, K.; Kervyn,

M.; Walraevens, K. Hydrochemical

Characterisation of High-Fluoride

Groundwater and Development of a

Conceptual Groundwater Flow

Model Using a Combined

Hydrogeological and Hydrochemical

Approach on an Active Volcano:

Mount Meru, Northern Tanzania.

Water 2021, 13, 2159. https://

doi.org/10.3390/w13162159

Academic Editors: Maurizio Polemio and Konstantinos Voudouris

Received: 14 July 2021

Accepted: 2 August 2021

Published: 6 August 2021

Publisher's Note: MDPI stays neutral with regard to jurisdictional claims in published maps and institutional affiliations.

Copyright: (c) 2021 by the authors. Licensee MDPI, Basel, Switzerland. This article is an open access article distributed under the terms and conditions of the Creative Commons Attribution (CC BY) license (https:/ / creativecommons.org/licenses/by/ $4.0 /)$.
1 Laboratory for Applied Geology and Hydrogeology, Department of Geology, Ghent University, 9000 Gent, Belgium; Jill.VanReybrouck@UGent.be (J.V.R.); Kristine.Walraevens@UGent.be (K.W.)

2 Department of Mining and Mineral Processing Engineering, University of Dodoma, Dodoma P.O. Box 259, Tanzania

3 Department of Geology, University of Dodoma, Dodoma P.O. Box 259, Tanzania; 7ceven@gmail.com (C.S.); Mary.John.Kisaka@vub.be (M.K.)

4 Physical Geography (FARD), Department of Geography, Vrije Universiteit Brussel, 1050 Brussels, Belgium; ines.tomasek@uca.fr (I.T.); matthieu.kervyn.de.meerendre@vub.be (M.K.)

5 Analytical, Environmental and Geochemistry (AMGC), Department of Chemistry, Vrije Universiteit Brussel, 1050 Brussels, Belgium

6 Laboratoire Magmas et Volcans, CNRS, IRD, OPGC, Université Clermont Auvergne, 63000 Clermont-Ferrand, France

7 Institute of Genetic Reproduction and Development, CNRS UMR 6293, INSERM U1103, Université Clermont Auvergne, 63000 Clermont-Ferrand, France

8 Laboratoire G-Time, Department of Geosciences, Environment and Society, Université libre de Bruxelles, 1050 Brussels, Belgium; Karen.Fontijn@ulb.be

* Correspondence: gbennett@udom.ac.tz

Abstract: This study characterises high-fluoride groundwater in the aquifer system on the flanks of Mount Meru, focusing on parts of the flanks that were only partially or not at all covered by previous research. Additionally, we analyse the impact of rainwater recharge on groundwater chemistry by monitoring spring discharges during water sampling. The results show that the main groundwater type in the study area is $\mathrm{NaHCO}_{3}$ alkaline groundwater (average $\mathrm{pH}=7.8$ ). High $\mathrm{F}^{-}$ values were recorded: in 175 groundwater samples, the concentrations range from 0.15 to $301 \mathrm{mg} / \mathrm{L}$ (mean: $21.89 \mathrm{mg} / \mathrm{L}$, median: $9.67 \mathrm{mg} / \mathrm{L}$ ), with $91 \%$ of the samples containing $\mathrm{F}^{-}$values above the WHO health-based guideline for drinking water $(1.5 \mathrm{mg} / \mathrm{L})$, whereas $39 \%$ of the samples have $\mathrm{Na}+$ concentrations above the WHO taste-based guideline of $200 \mathrm{mg} / \mathrm{L}$. The temporal variability in $\mathrm{F}^{-}$ concentrations between different seasons is due to the impact of the local groundwater recharge. We recommend that a detailed ecohydrological study should be carried out for the low-fluoride springs from the high-altitude recharge areas on the eastern and northwestern flanks of Mount Meru inside Arusha National Park. These springs are extracted for drinking purposes. An ecohydrological study is required for the management of these springs and their potential enhanced exploitation to ensure the sustainability of this water extraction practice. Another strategy for obtaining safe drinking water could be to use a large-scale filtering system to remove $\mathrm{F}^{-}$from the groundwater.

Keywords: groundwater quality; groundwater resource management; alkaline groundwater; high fluoride concentration; volcanic aquifer; Mount Meru; Tanzania; East African Rift System 


\section{Introduction}

In Tanzania, the availability of water is constricted by the increasing water needs due to a rapid population growth and ongoing climate change that is responsible for repeated drought episodes and the drying up of surface water bodies [1]. Groundwater is the main source of domestic water supply for both urban and rural areas in Tanzania, which consumes about $60 \%$ of total groundwater use whereas irrigation, mining and industrial use, livestock, and dry land fishing consume $40 \%$ [1]. The main challenges for groundwater quantity are depletion of shallow aquifers due to over-pumping, climate change, conflicting land uses, and uncontrolled urban development [1-3]. The main challenges for groundwater quality are high $\mathrm{F}^{-}$concentration [3-7], contamination from domestic sewage from on-site sanitation, industrial effluents, leachates from solid waste dumpsites, leaking fuel filling and waste oils [2], and saltwater intrusion (saltwater pollution) in coastal areas due to over-pumping of the aquifer [2,8].

The East African Rift System contains some of the regions with the highest $\mathrm{F}^{-}$concentrations in the world: Kenya, Tanzania, and Ethiopia [9]. High $\mathrm{F}^{-}$concentrations exceeding the WHO health-based guideline for drinking water $(1.5 \mathrm{mg} / \mathrm{L})$ [10] have been reported in both the surface and groundwater in Tanzania [2-7,11], Ethiopia [12,13], and Kenya [14-16]. The regions are rich in highly weathered $\mathrm{Na}-\mathrm{K}$-rich volcanic rocks with low $\mathrm{Ca}-\mathrm{Mg}$ content. The weathering and dissolution of these rocks in combination with other processes such as calcite precipitation produce $\mathrm{NaHCO}_{3}$ waters and alkaline groundwaters with $\mathrm{pH}>7$. These alkaline groundwaters with very low or absent $\mathrm{Ca}-\mathrm{Mg}$ contents favor the dissolution of fluorite $\left(\mathrm{CaF}_{2}\right)$ or fluorapatite $\left(\mathrm{Ca}_{5}\left(\mathrm{PO}_{4}\right)_{3} \mathrm{~F}\right)$; hence, high $\mathrm{F}^{-}$concentrations are observed [5,15]. However, this problematic is not only constrained to the East African Rift System: other African countries affected by the problem include Algeria, Ghana, Malawi, Nigeria, South Africa, Sudan, and Uganda $[9,17]$.

In the Arusha volcanic region in northern Tanzania, within the eastern branch of the East African Rift System, several studies have been conducted on the water quality and hydrogeochemical characteristics of surface and groundwater around Mount Meru, with a focus on $\mathrm{F}^{-}$concentration. The study by Kilham and Hecky [18] which covered the Ngarenanyuki river and the closed basin lakes (Momella lakes, Lake Tulusia and Lake Rishateni) on the slopes of Mount Meru identified that the chemical weathering of crystalline rocks is the primary hydrogeochemical process controlling water chemistry and $\mathrm{F}^{-}$concentration in surface waters in the area. The study also identified that in the closed basin lakes, the evaporative concentration and carbonate precipitation are other processes playing a role. The study by Nanyaro et al. [11] on the eastern and southeastern flanks of Mount Meru identified that natural waters in some rivers, springs, alkaline ponds, and lakes are characterised by exceptionally high $\mathrm{F}^{-}$values due to the weathering of $\mathrm{F}^{-}$-rich nephelinitic and carbonatitic rocks and soil, whereas in the rivers draining the Mount Meru crater, gaseous emanations through mineral springs may also contribute to the high concentrations. Additionally, the study identified that the flushing of $\mathrm{F}^{-}$-rich $\mathrm{NaHCO}_{3}$ evaporitic salt (locally called "magadi") from the surface and top soil at the onset of the rainy season affects the $\mathrm{F}^{-}$concentrations in shallow groundwater and in surface water bodies, due to the preceding continuous evaporative enrichment during the dry season. Furthermore, the study by Ghiglieri et al. [5] on the eastern and northern flanks of Mount Meru found that samples collected from springs, one borehole, and surface water showed that mineral dissolution, exchange processes, and precipitation of $\mathrm{Ca}^{2+}$ from supersaturated solutions, joined with local permeability and hydraulic gradients, control the distribution of $\mathrm{F}^{-}$concentration in the area. Kitalika et al. [19] reported the variations of $\mathrm{F}^{-}$concentrations in the four rivers (Temi, Nduruma, Tengeru, and Maji ya Chai) on the southern flank of Mount Meru. The study found that the $\mathrm{F}^{-}$containing rocks exposed to $\mathrm{pH}$ above 7.6 display high leaching of $\mathrm{F}^{-}$in solution, which gradually increased with the increase in $\mathrm{pH}$, indicating that the dissolution of $\mathrm{F}^{-}$in water is a function of $\mathrm{pH}$. The study by Chacha et al. [6] on the southern flank of Mount Meru found that high $\mathrm{F}^{-}$concentration and general groundwater chemistry $\left(\mathrm{NaHCO}_{3}\right.$ water type) are more controlled by aquifer 
lithology than by anthropogenic activities. This study identified two potential aquifers in the area, both containing significant concentration of $\mathrm{F}^{-}$. Additionally, the study by Makoba and Muzuka [7] on the northern and southeastern flanks of Mount Meru found that surface and groundwater chemistry are controlled by geology, water-rock interaction time, and climatic conditions. This study found that the aquifer composed of fractured mafic volcanics, breccia, and tuffs shows low total dissolved solids (TDS) and $\mathrm{F}^{-}$values compared to the aquifer composed of lahars, which are susceptible to weathering and hence lead to high TDS and $\mathrm{F}^{-}$values. These lahars have been re-interpreted as debris avalanche for a main part by Delcamp et al. [20]. The study also recognised the contribution of anthropogenic pollution in few cases.

The present research investigates the hydrochemistry of high-fluoride groundwater on the eastern, northern, western, and southwestern flanks of Mount Meru. Parts of the western and southwestern flanks were partially covered by previous studies, whereas the far east of the eastern flank (i.e., on the northern flank of Ngurdoto crater) was not investigated before. The hydrochemical characterisation is presented in this paper. The detailed study of hydrochemical processes, resulting in the observed groundwater compositions, and the origin of fluoride in the groundwater, is the subject of a parallel paper (Bennett et al., in preparation). Moreover, the study analyses the impact of rainwater recharge on the groundwater chemistry by monitoring spring discharges during water sampling, which has not been previously characterised in the area.

\section{Materials and Methods}

2.1. Study Area

2.1.1. Location, Topography, and Climate

The study area covers the eastern, western, and northern flanks of Mount Meru volcano, and it occupies about $1000 \mathrm{~km}^{2}$ in the Arusha region, northern Tanzania (Figure 1). The relief map of Mount Meru in Figure 1 was derived from the Advanced Spaceborne Thermal Emission and Reflection Radiometer Global Digital Elevation Model Version 2 (ASTER GDEM 2), with 30-meter spatial resolution [21]. Mount Meru is situated in the Arusha National Park (ANAPA) just north of the city of Arusha. It is located $70 \mathrm{~km}$ west of Mount Kilimanjaro. The city of Arusha has a population of 416,442 inhabitants, while the Arusha district and Meru district have populations of 323,198 and 268,144 inhabitants, respectively [22] (p. 26). The study covers most parts of the Meru and Arusha districts.

The topography of the study area is dominated by Mount Meru, which is a steep stratovolcano with a summit culminating at $4565 \mathrm{~m}$ summit [23], but the highest elevation in the relief map in Figure 1 is 4532; this is due to the limitation of the ASTER GDEM 2 dataset. Our study area covers most of its slopes. The eastern flank of Mount Meru is incised by a deep valley formed by a catastrophic sector collapse that left a horseshoeshaped valley now occupied by an ash cone that last erupted in 1910 [20]. Multiple parasitic cones are notable features in the vicinity $[20,23,24]$.

Rainfall data from four existing rainfall stations-Agricultural Seed Agency (ASA) Farm at Ngaramtoni with 50 years data trend (1969-2018), Arusha Airport with 51 years data trend (1960-2010), Arusha Urban Water Supply and Sanitation Authority (AUWSA) with 27 years data trend (1992-2018), and Tengeru Livestock Institute with 29 years data trend (1990-2018) - were used to analyse long-term trends and the amount of rainfall in the study area. The stations cover the southern and southwestern flanks. The average monthly rainfall data show that the area experiences a bimodal rainfall pattern (Figure 2a). The long "masika" rains extend from late February to late May, and the short "vuli" rains extend from early November to early January. The dry "kiangazi" season is from June to October. 

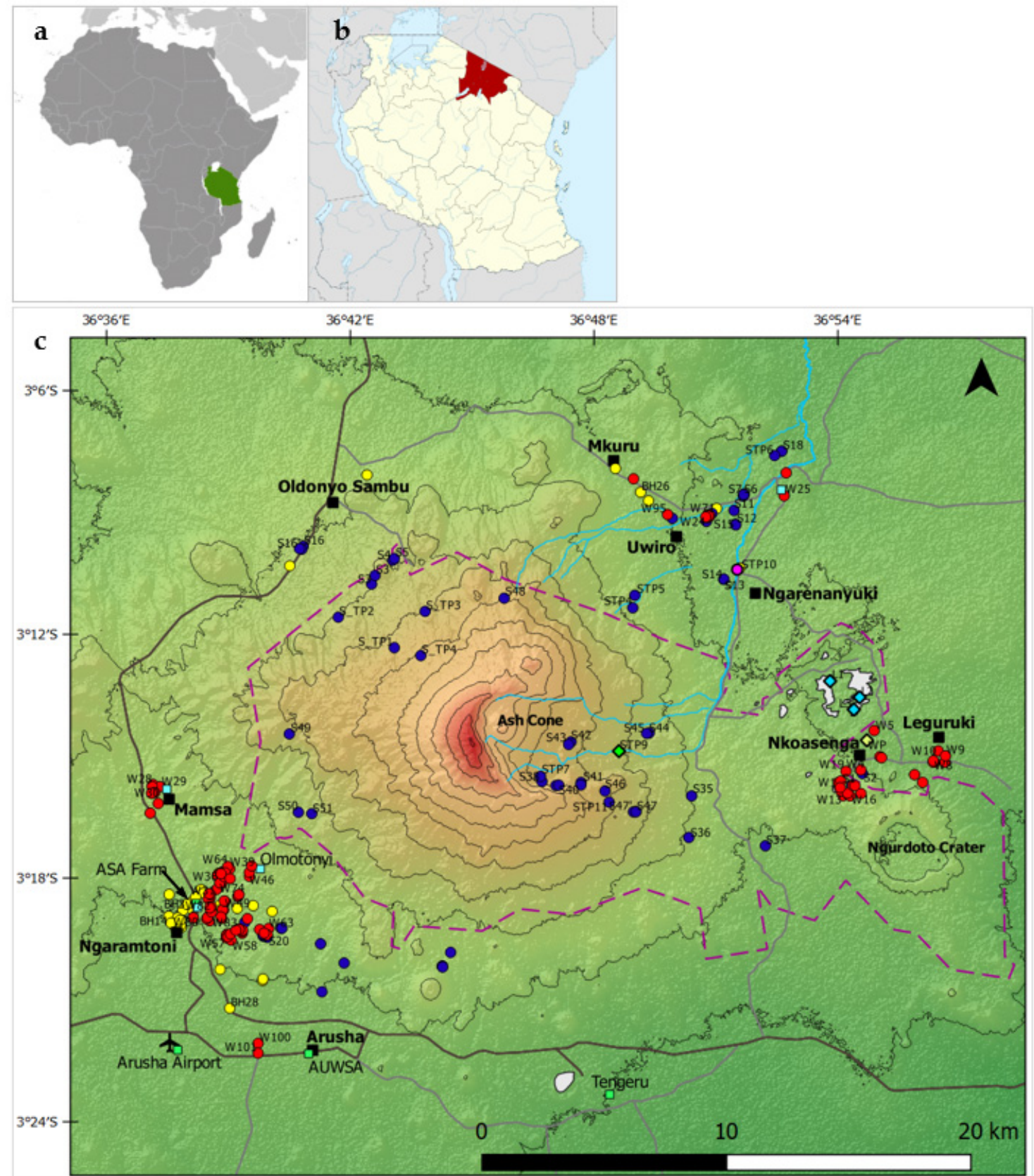

\section{Elevation (m.a.s.l.)}

$915-1800$

$1800-3200$

$3200-4532$
- Town and main villages

- Existing Rainfall Station

- New Rainfall Station

- - ANAPA Boundary

- Contours

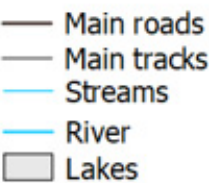

Lakes

\section{Water points}

- Well

$\checkmark$ Lake

- Spring

- River

- Borehole $\diamond$ Stream

$\diamond$ Water pond

ANAPA - Arusha National Park

Figure 1. (a) Map of Africa showing the location of Tanzania (Source: CIA [25], the image is copyright free), (b) map of Tanzania showing the Arusha region (Source: Wikipedia [26], the image is under an open access Creative Commons CC BY 4.0 license; credit line: Sémhur/Wikimedia Commons/CC-BY-SA-3.0) and (c) map showing the spatial distribution of inventoried water points in the study area (water points with label were sampled for chemical analysis). 


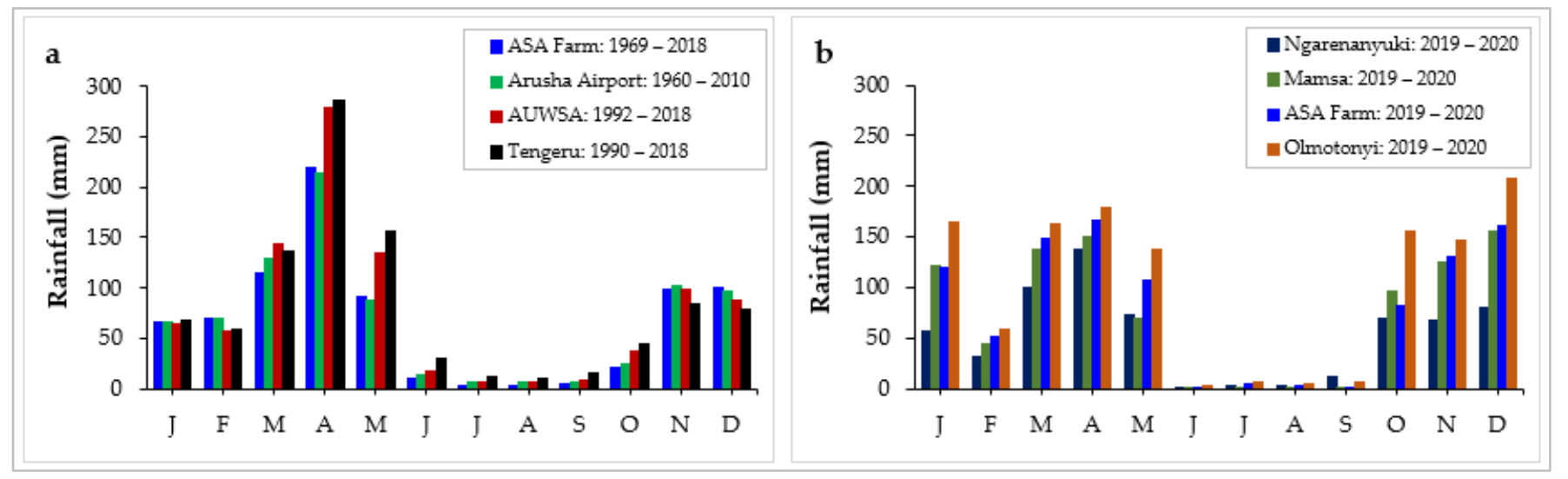

Figure 2. (a) Average monthly rainfall for the four existing rainfall stations and (b) average monthly rainfall for the four new installed rainfall stations.

The average annual rainfall at the two stations on the southwestern flank of Mount Meru; ASA Farm and Arusha Airport, is $800 \mathrm{~mm}$ and $822 \mathrm{~mm}$, respectively. On the southern flank, the average annual rainfall at the two stations, AUWSA and Tengeru, is $942 \mathrm{~mm}$ and $981 \mathrm{~mm}$, respectively. Four newly installed rainfall stations, each with 2 years of data trend (2019 and 2020), were used to analyse and compare the amount of rainfall on different flanks. Two stations are at Ngaramtoni (ASA Farm and Olmotonyi), one at Mamsa and one at Ngarenanyuki. The stations cover the southwestern, western, and northeastern flanks. Figure $2 \mathrm{~b}$ shows the average monthly rainfall for the stations. The average annual rainfall at the two stations on the southwestern flank, ASA Farm and Olmotonyi, is $977 \mathrm{~mm}$ and $1232 \mathrm{~mm}$, respectively, whereas on the western flank (at Mamsa), it is $905 \mathrm{~mm}$ and on the northeastern flank (at Ngarenanyuki), it is $638 \mathrm{~mm}$. The southern and eastern flanks of Mount Meru (windward sides) receive more rainfall than the western and northern flanks. The areas in the windward sides (eastern and southern flanks) experience a subtropical highland climate, while areas in the leeward sides (northern flank) experience a semi-arid climate (steppe climate). The temperature typically ranges from 13 to $30^{\circ} \mathrm{C}$ with an average annual temperature of about $25^{\circ} \mathrm{C}[6]$.

\subsubsection{Geological and Hydrogeological Setting}

Mount Meru is considered as an active stratovolcano located within the Northern Tanzanian Divergence Zone of the eastern branch of the East African Rift. It is characterised by alkaline magmatic activity, which is typical within the East African Rift System [4,20,23]. A large sector of its east flank was lost in the early Holocene due to a major collapse associated with the formation of large-scale debris avalanche deposits (DADs) between the base of Mount Meru and Kilimanjaro [20]. Meru last erupted in 1910 AD when a small amount of ash was ejected for a few days from the ash cone located within the large valley formed by the collapse. Significant fumarolic activity was recorded at the ash cone area until 1954 [23].

Most rocks within the area are Pleistocene volcanic-sedimentary sequences, but older sequences date back to the Miocene-Pliocene $[4,23,24,27]$. The lithology in the study area is dominated by volcanic rocks lava flows, pyroclastic, and debris avalanche deposits from the Mount Meru, with some alluvium, alluvial fan, and lake deposits found around the volcano base (Figure 3). Lava flows are found mainly at higher elevations on the main Mount Meru cone and on the southern flank, while the DADs, ash deposits, alluvium, alluvial fan deposits, and lake deposits are found at lower elevations at the base of Mount Meru. Pyroclastic deposits are mainly found on the western flank, whereas DADs are dominant on eastern and northern flanks. No crystalline basement rocks are exposed in the area, but Wilkinson et al. [23] reported that pegmatite and gneiss were recorded in a water borehole log west of Ngarenanyuki (northeastern part of the study area) at a depth 
of about $15 \mathrm{~m}$, implying that metamorphic rocks underlie the northern part of the study area at shallow depth.

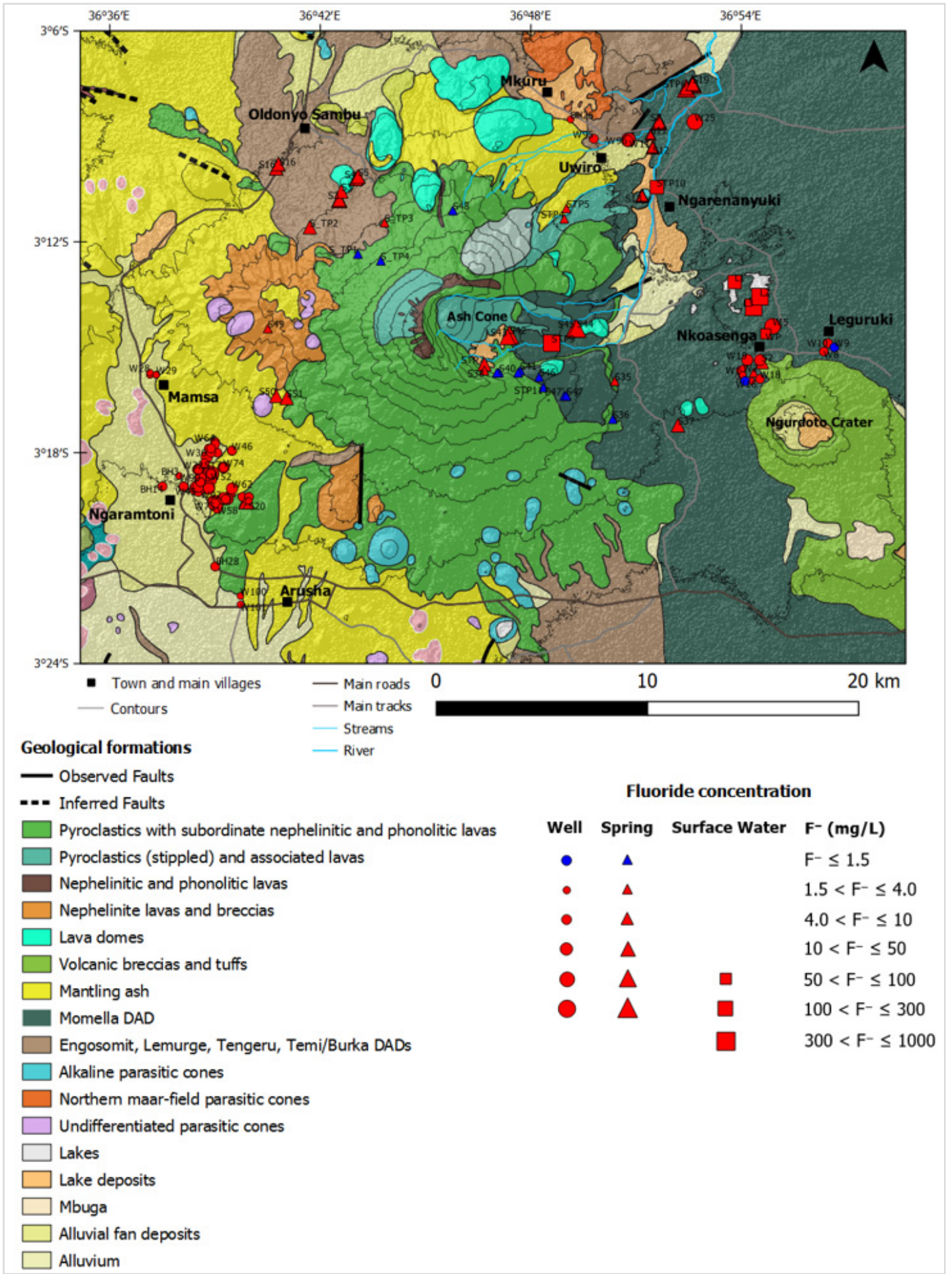

Figure 3. Geological map of the study area (modified after Wilkinson et al. [23] and Delcamp et al. [20]), indicating different geological formations and spatial distribution of $\mathrm{F}^{-}$concentrations of sampled water points. The geological descriptions are based on Wilkinson et al. [23] with updates from Delcamp et al. [20], who re-interpreted the deposits that had originally been mapped as lahar, as debris avalanche deposits (DADs). The deposits that had originally been mapped as tholoids by Wilkinson et al. [23] are now re-interpreted as lava domes in this study. 
Existing borehole completion reports and field stratigraphic descriptions of subsurface sediments during the digging of new hand-dug wells were used to characterise the geology of the aquifers. On the northeastern flank, data from one borehole at Mkuru (depth of around $65 \mathrm{~m}$ ) described by Ghiglieri et al. [4] and three hand-dug wells-one at Mkuru (depth of $23 \mathrm{~m}$ ) and two at Uwiro (depth of $4 \mathrm{~m}$ and $10 \mathrm{~m}$ )-were used to characterise the geology of the aquifer, whereas on the northern flank of Ngurdoto crater, data from two hand-dug wells were used: one at Nkoasenga (depth of $8 \mathrm{~m}$ ) and one at Leguruki (depth of $5 \mathrm{~m}$ ). On the western flank, data from two hand-dug wells at Mamsa (depth of $39 \mathrm{~m}$ and $42 \mathrm{~m}$ ) were used, whereas on the southwestern flank data from two boreholes (depth of $115 \mathrm{~m}$ and $150 \mathrm{~m}$ ) and eight hand-dug wells (depth range: 12-39 m) at Ngaramtoni were used. On the northeastern and southwestern flanks, there are two aquifers: a shallow and a deep aquifer. On the northeastern flank, the shallow aquifer in some area is unconfined and composed of debris avalanche deposits, while in another area, it is semi-confined and composed of weathered fractured lava with thickness more than $3 \mathrm{~m}$, whereas the deep aquifer is confined and composed of weathered fractured lava with thickness more than $30 \mathrm{~m}$. On the southwestern flank, the shallow aquifer is unconfined and composed of pyroclastic deposits with thickness more than $8 \mathrm{~m}$, whereas the deep aquifer is semi-confined and composed of weathered fractured lava and weathered pyroclastic deposits with thickness varying from 65 to $100 \mathrm{~m}$. On the western flank, the shallow aquifer is unconfined and composed of weathered fractured lava with thickness more than $3 \mathrm{~m}$, whereas on the northern flank of Ngurdoto crater, the shallow aquifer is unconfined, and it is composed of debris avalanche deposits with thickness more than $7 \mathrm{~m}$. The geomorphology of the landscape in the study area plays a great role in controlling the groundwater flow paths. The general groundwater flow system on each flank is involving a multidirectional flow from the higher elevation areas, including the parasitic cones, towards the lower areas.

\subsection{Inventory of Water Points}

Four field campaigns were conducted during July-September 2017, March-September 2018, February-August 2019, and April-December 2020. A total of 211 water points (205 groundwater and 6 surface water) were mapped and inventoried with the aim to quantify and characterise the groundwater resources on the flanks of Mount Meru (Figure 1). The 205 groundwater points consist of 104 hand-dug wells (depth range from 0.7 to $50 \mathrm{~m}$ ), 68 springs, and 33 boreholes (depth range from 48 to $170 \mathrm{~m}$ ). In this study, a well with depth greater than $50 \mathrm{~m}$ is considered as deep well; therefore, all hand-dug wells are classified as shallow wells, whereas one borehole is classified as a shallow well, and the rest are classified as deep wells. Shallow wells characterise the shallow aquifer, while deep wells characterise the deep aquifer. The 6 surface water points consist of 1 water pond, 1 stream (Njekukumia stream), 1 river (Ngarenanyuki river), and 3 lakes (Big Momella lake, Small Momella lake, and Lake Rishateni). For each water point, the following information was recorded: elevation, geographical coordinates (GPS), lithology, year of well/borehole construction, well/borehole depth and groundwater level (for the well/borehole), spring setting and spring discharge (for the spring), and uses of water. Each water point was identified by an alphanumeric code.

The distribution of water points is in six clusters located at Ngaramtoni and near Arusha town (southwestern flank), Mamsa (western flank), Oldonyo Sambu (northwestern flank), Mkuru, Uwiro, and Ngarenanyuki (north and northeastern flanks), eastern part of the Arusha National Park (eastern flank), and Nkoasenga and Leguruki (far east of the eastern flank). In Ngaramtoni and near Arusha town, the area is dry with scarce vegetation; there are many shallow hand-dug wells and boreholes but with few springs. In Mamsa, the area is dry with scarce vegetation, there are a few shallow hand-dug wells and only one spring on the slope of Mount Meru inside the Arusha National Park. In Oldonyo $\mathrm{Sambu}$, the area is very dry with scarce vegetation, two boreholes with depths of $55 \mathrm{~m}$ and $150 \mathrm{~m}$ respectively are found, but both did not reach groundwater, nor was any shallow hand-dug well found; this is probably due to the presence of very thick porous pyroclastic 
deposits, which led to deeper groundwater flow, and there is only one spring at the base of the Mount Meru with other springs located on the slope of the Mount Meru inside the Arusha National Park. In Mkuru, Uwiro, and Ngarenanyuki, the areas are very dry with few vegetation, there are few shallow hand-dug wells, boreholes, and springs with only one perennial river called "Ngarenanyuki River". On the eastern part of Arusha National Park, the area is very densely vegetated and green; there are numerous springs with two hydrothermal springs (S42-Small Njekukumia and S43-Big Njekukumia) located just at the foot of the ash cone on the collapsed eastern flank of Mount Meru. In this study, the names 'Small' and 'Big' specified to the Njekukumia springs were ascribed to their discharge. Their discharges were qualitatively assessed; the Big Njekukumia has high flow discharge compared to the Small Njekukumia. The springs have been characterised as hydrothermal springs by Ghiglieri et al. [5] and Nanyaro et al. [11]; they join to form the Njekukumia stream, which discharges its water to the Ngarenanyuki river. At lower elevations, in the discharge area, three lakes are found (L1—Small Momella Lake, L2-Big Momella Lake, and L3-Lake Rishateni). In Nkoasenga and Leguruki, the areas are very densely vegetated and green; there are several shallow hand-dug wells and only two springs. The hydrogeology of these areas is mainly influenced by the Ngurdoto crater due to its proximity and not the main Mount Meru.

\subsection{Sampling}

Water samples were collected in high-density polyethylene bottles with a capacity of $250 \mathrm{ml}$ and thoroughly pre-washed with water to be sampled. During sampling, an icebox cooler was used in the field to keep and transport samples before being stored under refrigeration. The samples were transported to Belgium and analysed for their chemical properties at the Laboratory for Applied Geology and Hydrogeology, Ghent University. A total of 181 water samples (175 groundwater and 6 surface water) from 128 water points were collected for chemical analysis from the four field campaigns. All 6 inventoried surface water points were sampled. It should be mentioned that the six surface water samples are not representative of all surface water in the study area, since they were sampled because of their known high $\mathrm{F}^{-}$concentrations. Table 1 summarises the distribution of groundwater samples that were collected from the inventoried groundwater points. From the 205 inventoried groundwater points, $60 \%(n=122)$ of the points were sampled. The sampling of the water points ensured a representative coverage of the whole study area. Few of the inventoried boreholes were sampled, because most of them are cased, as they are not in use, and others are connected into storage tanks that are inaccessible. Some of the hand-dug wells and springs were sampled more than once; this was done in order to study the variations with time in the $\mathrm{F}^{-}$concentrations in the groundwater. The selection of water points to be studied more in detail was based on the sampling of water points so as to have a representative coverage of the whole study area. The springs found in the Arusha National Park were not easily accessed due to their remoteness; thus, they were sampled once. All sampled hand-dug wells (shallow wells) were characterised as shallow aquifers, whereas one sampled borehole is a shallow well was characterised as a shallow aquifer, and the other three sampled boreholes are deep wells are characterised as deep aquifers. 
Table 1. Distribution of groundwater samples that were collected from the inventoried groundwater points.

\begin{tabular}{|c|c|c|c|c|c|c|}
\hline $\begin{array}{l}\text { Type of Water } \\
\text { Points }\end{array}$ & $\begin{array}{c}\text { Number of } \\
\text { Inventoried Points }\end{array}$ & $\begin{array}{c}\text { Number of } \\
\text { Sampled Points }\end{array}$ & $\begin{array}{c}\% \text { of Sampled } \\
\text { Points }\end{array}$ & $\begin{array}{l}\text { Number of } \\
\text { Samples }\end{array}$ & $\begin{array}{c}\text { Number of Samples per } \\
\text { Water Point }\end{array}$ & $\begin{array}{c}\text { Characteristic of } \\
\text { Sampled } \\
\text { Wells/Boreholes }\end{array}$ \\
\hline \multirow{3}{*}{ Hand-dug wells } & \multirow{3}{*}{104} & \multirow{3}{*}{66} & \multirow{3}{*}{63} & \multirow{3}{*}{86} & $\begin{array}{l}3 \text { points were sampled } \\
\text { three times }\end{array}$ & \multirow{3}{*}{ Shallow wells } \\
\hline & & & & & $\begin{array}{l}14 \text { points were } \\
\text { sampled twice }\end{array}$ & \\
\hline & & & & & $\begin{array}{l}49 \text { points were } \\
\text { sampled once }\end{array}$ & \\
\hline \multirow{4}{*}{ Springs } & \multirow{4}{*}{68} & \multirow{4}{*}{52} & \multirow{4}{*}{68} & \multirow{4}{*}{85} & $\begin{array}{l}2 \text { points were sampled } \\
\text { five times }\end{array}$ & \\
\hline & & & & & $\begin{array}{l}10 \text { points were sampled } \\
\text { three times }\end{array}$ & \\
\hline & & & & & $\begin{array}{l}5 \text { points were } \\
\text { sampled twice }\end{array}$ & \\
\hline & & & & & $\begin{array}{l}35 \text { points were } \\
\text { sampled once }\end{array}$ & \\
\hline \multirow{2}{*}{ Boreholes } & \multirow{2}{*}{33} & \multirow{2}{*}{4} & \multirow{2}{*}{12} & 1 & Samples once & Shallow well \\
\hline & & & & 3 & Each point sampled once & Deep wells \\
\hline
\end{tabular}

\subsection{Field Measurements}

During the four field campaigns conducted in the framework of this study, a portable Aquaread AP-700 device was employed in the field to measure in situ physicochemical properties of water samples including temperature, $\mathrm{pH}$, oxidation-reduction potential (ORP), dissolved oxygen (DO), and electrical conductivity (EC). The device also records geographical coordinates (GPS), elevation, date, and time of measurement. Additionally, the device gives the calculated readings of resistivity (RES), total dissolved solids (TDS), salinity (SAL), and seawater specific gravity (SSG) based on the EC and temperature measurements. A total of 174 in situ measurements from 126 water points were recorded from the four field campaigns.

\subsection{Laboratory Analysis}

Chemical analyses were performed in the Laboratory for Applied Geology and Hydrogeology at Ghent University. Different analytical methods were applied to determine the concentration of various hydrochemical parameters. The $\mathrm{pH}$ was measured using a $\mathrm{pH}$ meter while the electrical conductivity was measured using an electronic EC meter. The samples that were used for cation analysis after filtration $(0.45 \mu \mathrm{m})$ were brought to a $\mathrm{pH}$ of around 2 prior to analysis by adding ultra-pure nitric acid. The following cations were measured: sodium $\left(\mathrm{Na}^{+}\right)$, potassium $\left(\mathrm{K}^{+}\right)$, magnesium $\left(\mathrm{Mg}^{2+}\right)$, iron $\left(\mathrm{Fe}^{2+} / \mathrm{Fe}^{3+}\right)$, manganese $\left(\mathrm{Mn}^{2+}\right)$, ammonium $\left(\mathrm{NH}_{4}^{+}\right)$, and silicon $\left(\mathrm{Si}^{4+}\right)$. Concentration of $\mathrm{Na}^{+}, \mathrm{K}^{+}, \mathrm{Ca}^{2+}, \mathrm{Fe}^{2+} / \mathrm{Fe}^{3+}$, $\mathrm{Mg}^{2+}, \mathrm{Mn}^{2+}$, and $\mathrm{Si}^{4+}$ were determined in a diluted solution using flame atomic absorption spectroscopy (AAS) using a Varian Zeeman Spectra AA 400. The concentration of $\mathrm{NH}_{4}{ }^{+}$ was measured using the molecular absorption spectrophotometer UV-VIS Shimadzu UV mini 1240. Anions (chloride $\left(\mathrm{Cl}^{-}\right)$, sulphate $\left(\mathrm{SO}_{4}{ }^{2-}\right)$, nitrate $\left(\mathrm{NO}_{3}{ }^{-}\right)$, and nitrite $\left(\mathrm{NO}_{2}{ }^{-}\right)$ were measured using the molecular absorption spectrophotometer UV-VIS Shimadzu UV mini 1240. Carbonate $\left(\mathrm{CO}_{3}{ }^{2-}\right)$ and bicarbonate $\left(\mathrm{HCO}_{3}{ }^{-}\right)$contents were obtained by titration with dilute $\mathrm{HCl}$ acid, but during the analysis, the tipping point between them at $\mathrm{pH}=8.2$ was not determined analytically with sufficient accuracy, suggesting that the distribution of $\mathrm{HCO}_{3}{ }^{-}$and $\mathrm{CO}_{3}{ }^{2-}$ in the samples is strongly variable with $\mathrm{pH}$; hence, it was impossible to measure it accurately using $\mathrm{pH}$ as the criterion. Therefore, in this study, the total alkalinity (TA), which is the sum of $\mathrm{HCO}_{3}{ }^{-}$and $\mathrm{CO}_{3}{ }^{2-}$, is expressed as $\mathrm{mg} / \mathrm{L}$ $\mathrm{HCO}_{3}{ }^{-}$. The fluoride $\left(\mathrm{F}^{-}\right)$was measured using an ion selective electrode (ISE). Detailed descriptions of the different analytical methods are extensively explained in the laboratory manual and in standard methods for examination of water and wastewater [28]. 


\subsection{Data Processing and Analysis}

The hydrochemical characterisation of groundwater in the study area has been investigated based on the analysis of a Schoeller diagram, Piper diagram, bivariate diagrams, and statistical analyses.

The concentrations of $\mathrm{F}^{-}$determined in water samples were compared to the maximum permissible limits for drinking water set by the WHO $(1.5 \mathrm{mg} / \mathrm{L})$ and Tanzanian standards $(4.0 \mathrm{mg} / \mathrm{L})$.

Major physicochemical parameters were tested for normality using IBM SPSS Statistics 27 software. Considering that all were not normally distributed, the Spearman's correlation was used for analysis. Since the IBM SPSS Statistics 27 reported all the significant $p$-values for this test as 0.000 (only in three decimal places), the calculation of $p$-values in more decimal places was done using Microsoft Excel 2019. A Mann-Whitney U Test was carried out to assess whether the $\mathrm{F}^{-}$concentrations in September 2017 and September 2018 (two different dry seasons) are significantly different.

\section{Results and Discussion}

Table 2 summarises descriptive statistics: minimum, maximum, mean, median, standard deviation, and coefficient of variation for the physicochemical parameters of the water samples analysed in this study. On average, the springs show low concentrations of the different hydrogeochemical parameters followed by the deep wells, shallow wells, and lastly the surface waters (river, water pond, stream, lakes) except for $\mathrm{NH}_{4}{ }^{+}, \mathrm{NO}_{3}{ }^{-}$, and $\mathrm{NO}_{2}{ }^{-}$, which are depleted in surface waters due to their uptake by aquatic organisms. All the physicochemical parameters show high variability as revealed by very high coefficients of variation; this may be due to the complexity of groundwater flow passing through different geological formations of variable weatherability [29] and variable residence times. Overall, the water samples contain concentrations in the order of $\mathrm{Na}^{+}>\mathrm{K}^{+}>\mathrm{Ca}^{2+}>\mathrm{Mg}^{2+}$ $>\mathrm{Fe}^{2+} / \mathrm{Fe}^{3+}>\mathrm{Mn}^{2+}>\mathrm{NH}_{4}{ }^{+}$for cations and $\mathrm{HCO}_{3}{ }^{-}+\mathrm{CO}_{3}{ }^{2-}>\mathrm{SO}_{4}{ }^{2-}>\mathrm{Cl}^{-}>\mathrm{NO}_{3}{ }^{-}>$ $\mathrm{F}^{-}>\mathrm{NO}_{2}{ }^{-}$for anions. Figure 4 shows the concentrations of major ions for all analysed water samples in this study. $\mathrm{Na}^{+}$is the dominant cation in $99 \%(\mathrm{n}=180)$ of the analysed water samples $(\mathrm{n}=181)$, whereas $\mathrm{HCO}_{3}{ }^{-}+\mathrm{CO}_{3}{ }^{2-}$ is the dominant anion in all samples; therefore, the main water type for both surface water and groundwater in the area is $\mathrm{NaHCO}_{3}$ (Figure 5) [30].

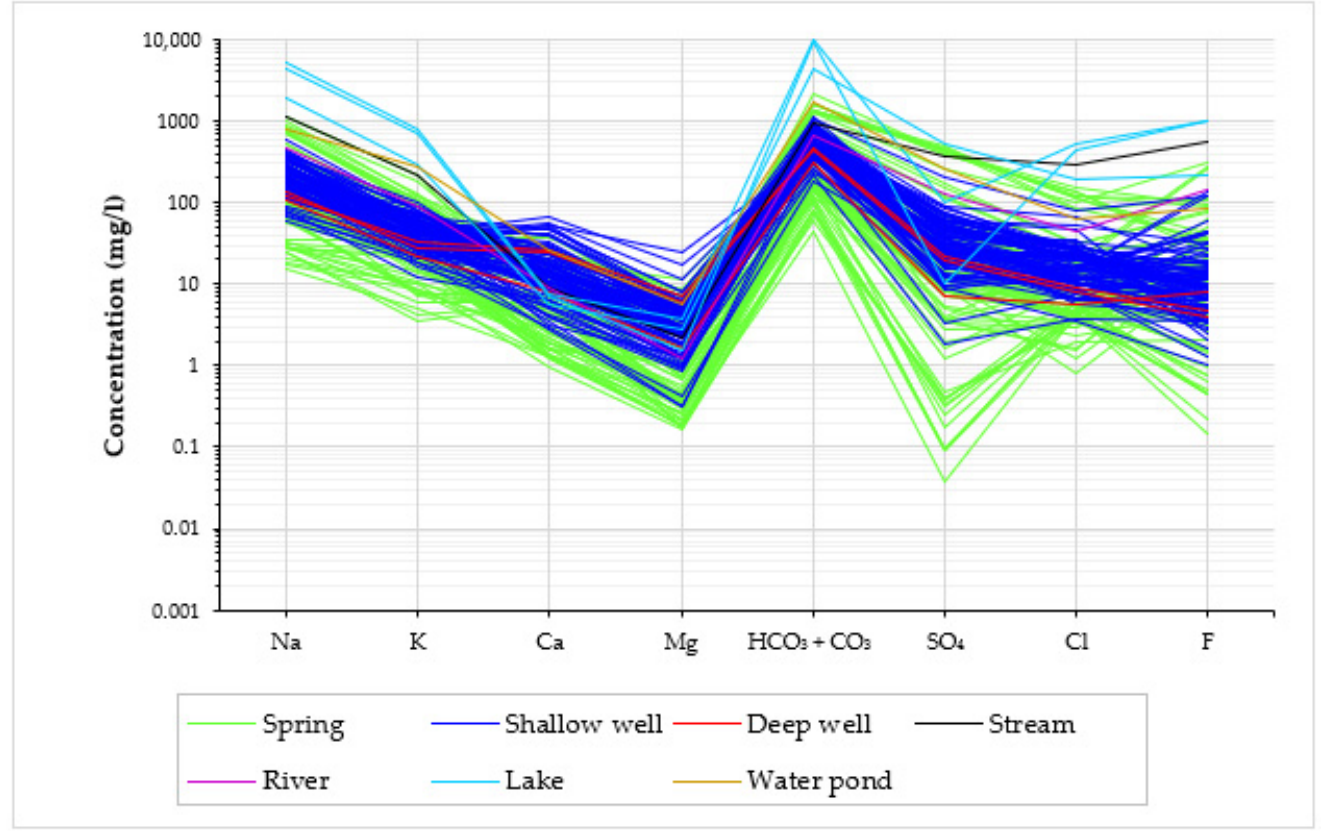

Figure 4. Schoeller diagram showing the concentrations of major ions. 


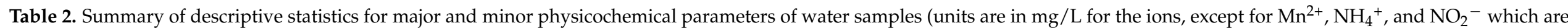
in $\mu \mathrm{g} / \mathrm{L}$, the $\mathrm{pH}$ is unitless and $\mathrm{EC}$ is in $\mu \mathrm{S} / \mathrm{cm}$ at $25^{\circ} \mathrm{C}$. n: number of samples; SD: standard deviation; $\mathrm{CV}$ : coefficient of variation; ${ }^{*}$ as $\mathrm{mg} / \mathrm{L} \mathrm{HCO}{ }^{-}$).

\begin{tabular}{|c|c|c|c|c|c|c|c|c|c|c|c|c|c|c|c|c|c|c|c|}
\hline \multicolumn{2}{|c|}{ Water Type } & $\mathrm{pH}$ & EC & $\mathrm{Na}^{+}$ & $\mathrm{K}^{+}$ & $\mathrm{Ca}^{2+}$ & $\mathrm{Mg}^{2+}$ & $\mathrm{Fe}^{2+} / \mathrm{Fe}^{3+}$ & $\mathrm{Mn}^{2+}$ & $\mathrm{NH}_{4}{ }^{+}$ & $\mathrm{F}^{-}$ & $\mathrm{Cl}^{-}$ & $\mathrm{SO}_{4}{ }^{2-}$ & $\mathrm{NO}_{3}{ }^{-}$ & $\mathrm{NO}_{2}{ }^{-}$ & $\left(\mathrm{HCO}_{3}^{-}+\mathrm{CO}_{3}^{2-}\right)^{*}$ & $\mathrm{PO}_{4}{ }^{3-}$ & $\mathrm{SiO}_{2}$ & TDS \\
\hline \multicolumn{20}{|c|}{ Eastern flank } \\
\hline \multirow{6}{*}{ Springs $(n=16)$} & Min & 7.1 & 105 & 15.1 & 3.5 & 1.0 & 0.2 & 0.03 & 0.0 & 0.0 & 0.1 & 1.7 & 0.0 & 0.0 & 0.0 & 44.5 & 0.00 & 27.2 & 117 \\
\hline & Max & 8.6 & 1183 & 425 & 58 & 11.9 & 0.9 & 0.14 & 7.0 & 10 & 274 & 19 & 68 & 5.4 & 11 & 330 & 0.79 & 61.1 & 1184 \\
\hline & Mean & 7.7 & 339 & 80 & 19.6 & 5.8 & 0.4 & 0.06 & 2.0 & 2.0 & 36.1 & 6.6 & 9.2 & 2.3 & 1.0 & 137 & 0.32 & 38.8 & 336 \\
\hline & Median & 7.7 & 231 & 28.4 & 13.4 & 5.8 & 0.4 & 0.05 & 0.0 & 0.0 & 1.4 & 5.0 & 0.4 & 2.2 & 0.0 & 114 & 0.15 & 37.5 & 221 \\
\hline & SD. & 0.4 & 327 & 131 & 16.6 & 3.6 & 0.2 & 0.03 & 3.0 & 3.0 & 89 & 4.8 & 23 & 1.3 & 3.0 & 82 & 0.33 & 7.6 & 333 \\
\hline & CV $(\%)$ & 5 & 96 & 163 & 84 & 62 & 53 & 52 & 145 & 155 & 247 & 73 & 248 & 58 & 202 & 60 & 102 & 20 & 99 \\
\hline \multirow{2}{*}{\multicolumn{2}{|c|}{$\begin{array}{l}\text { Hydrothermal springs } \\
\qquad(\mathrm{n}=2)\end{array}$}} & 8.2 & 3650 & 899 & 179 & 8.4 & 1.6 & 0.07 & 0.0 & 0.0 & 301 & 100 & 260 & 2.5 & 4.0 & 1287 & 0.00 & 31.4 & 3070 \\
\hline & & 8.5 & 4590 & 1123 & 216 & 3.8 & 2.3 & 0.04 & 6.0 & 16 & 95.2 & 148 & 418 & 0.9 & 0.0 & 2170 & 0.96 & 36.3 & 4214 \\
\hline \multicolumn{2}{|c|}{ Stream $(\mathrm{n}=1)$} & 9.1 & 4390 & 1140 & 220 & 9.1 & 2.2 & 0.06 & 0.0 & 0.0 & 553 & 295 & 377 & 1.1 & 0.0 & 914 & 0.79 & 27.6 & 3540 \\
\hline \multirow{6}{*}{ Lakes $(\mathrm{n}=3)$} & Min & 9.5 & 8630 & 1928 & 283 & 5.7 & 1.5 & 0.12 & 1.0 & 0.0 & 217 & 192 & 10.4 & 5.1 & 3.0 & 4285 & 2.0 & 0.3 & 7438 \\
\hline & Max & 10.1 & 19820 & 5190 & 801 & 7.6 & 3.8 & 0.18 & 5.0 & 0.0 & 1004 & 512 & 517 & 7.1 & 51 & 9863 & 6.5 & 2.2 & 17495 \\
\hline & Mean & 9.8 & 15340 & 3786 & 599 & 6.8 & 2.7 & 0.15 & 2.0 & 0.0 & 736 & 379 & 209 & 6.0 & 32 & 7811 & 3.5 & 1.1 & 13541 \\
\hline & Median & 9.9 & 17570 & 4240 & 714 & 7.3 & 2.7 & 0.16 & 1.0 & 0.0 & 988 & 434 & 102 & 6.0 & 41 & 9285 & 2.0 & 0.9 & 15691 \\
\hline & SD. & 0.3 & 5919 & 1678 & 277 & 1.0 & 1.1 & 0.03 & 2.0 & 0.0 & 450 & 167 & 270 & 1.0 & 25 & 3067 & 2.6 & 1.0 & 5362 \\
\hline & CV $(\%)$ & 3 & 39 & 44 & 46 & 15 & 42 & 22 & 99 & & 61 & 44 & 129 & 16 & 79 & 39 & 75 & 88 & 40 \\
\hline \multicolumn{20}{|c|}{ Far east of the eastern flank (Northern flank of Ngurdoto crater) } \\
\hline \multirow{2}{*}{\multicolumn{2}{|c|}{ Springs $(\mathrm{n}=2)$}} & 7.2 & 632 & 106 & 26.2 & 14.0 & 2.4 & 0.02 & 8.0 & 75 & 2.6 & 13.4 & 19.8 & 10.0 & 2.0 & 334 & 0.05 & 44.5 & 573 \\
\hline & & 7.6 & 919 & 171 & 42.8 & 2.4 & 0.4 & 0.02 & 12 & 38 & 10.7 & 3.3 & 25.7 & 23.5 & 78 & 478 & 0.60 & 30.8 & 789 \\
\hline \multirow{5}{*}{$\begin{array}{l}\text { Shallow wells } \\
\qquad(\mathrm{n}=13)\end{array}$} & Max & 8.4 & 1932 & 443 & 60.1 & 28.9 & 7.1 & 36.4 & 300 & 67 & 133.7 & 26.3 & 68.7 & 101.1 & 1292 & 756 & 1.17 & 195 & 1644 \\
\hline & Mean & 7.8 & 788 & 134 & 34.3 & 11.5 & 2.4 & 7.26 & 82 & 16 & 18.8 & 10.4 & 27.3 & 22.5 & 188 & 355.9 & 0.48 & 112 & 737 \\
\hline & Median & 8.1 & 740 & 117 & 30.4 & 9.4 & 1.8 & 0.06 & 60 & 0.0 & 4.5 & 9.1 & 21.9 & 5.3 & 0.0 & 342.5 & 0.49 & 147 & 640 \\
\hline & SD. & 0.5 & 381 & 100.0 & 14.0 & 7.8 & 1.8 & 11.9 & 96 & 23 & 36.7 & 5.7 & 18.1 & 31.6 & 457 & 143 & 0.39 & 64.7 & 294 \\
\hline & $\mathrm{CV}(\%)$ & 6 & 48 & 74 & 41 & 68 & 72 & 164 & 118 & 150 & 195 & 55 & 66 & 141 & 244 & 40 & 81 & 58 & 40 \\
\hline \multicolumn{2}{|c|}{ Water pond $(\mathrm{n}=1)$} & 9.2 & 4310 & 789 & 268.5 & 25.7 & 5.7 & 0.20 & 19 & 45 & 85.9 & 62.1 & 254 & 5.9 & 126 & 1730 & 8.19 & 1.9 & 3237 \\
\hline \multicolumn{20}{|c|}{ North-eastern flank } \\
\hline \multirow{6}{*}{ Springs $(\mathrm{n}=27)$} & Min & 6.9 & 292 & 58.7 & 8.1 & 1.3 & 0.4 & 0.00 & 0.0 & 0.0 & 3.0 & 2.3 & 4.9 & 2.1 & 0.0 & 151 & 0.00 & 15.6 & 276 \\
\hline & Max & 8.6 & 3510 & 1012 & 124 & 36.0 & 11.2 & 0.50 & 400 & 345 & 113 & 136 & 499 & 59.1 & 3731 & 1643 & 1.68 & 210 & 3560 \\
\hline & Mean & 7.8 & 1809 & 393 & 58.8 & 13.8 & 4.1 & 0.08 & 37 & 67 & 30.0 & 44.7 & 169 & 15.9 & 280 & 820 & 0.44 & 65.6 & 1616 \\
\hline & Median & 7.8 & 1205 & 224 & 49.4 & 12.2 & 3.5 & 0.06 & 3.0 & 11 & 12.5 & 18.4 & 58.3 & 11.3 & 2.0 & 716 & 0.21 & 48.2 & 1105 \\
\hline & SD. & 0.5 & 1162 & 286 & 33.7 & 7.0 & 2.4 & 0.12 & 92 & 95 & 33.2 & 46.9 & 181 & 14.9 & 765 & 453 & 0.51 & 56.2 & 1002 \\
\hline & CV (\%) & 7 & 64 & 73 & 57 & 51 & 58 & 142 & 246 & 142 & 111 & 105 & 107 & 94 & 274 & 55 & 117 & 86 & 62 \\
\hline
\end{tabular}


Table 2. Cont

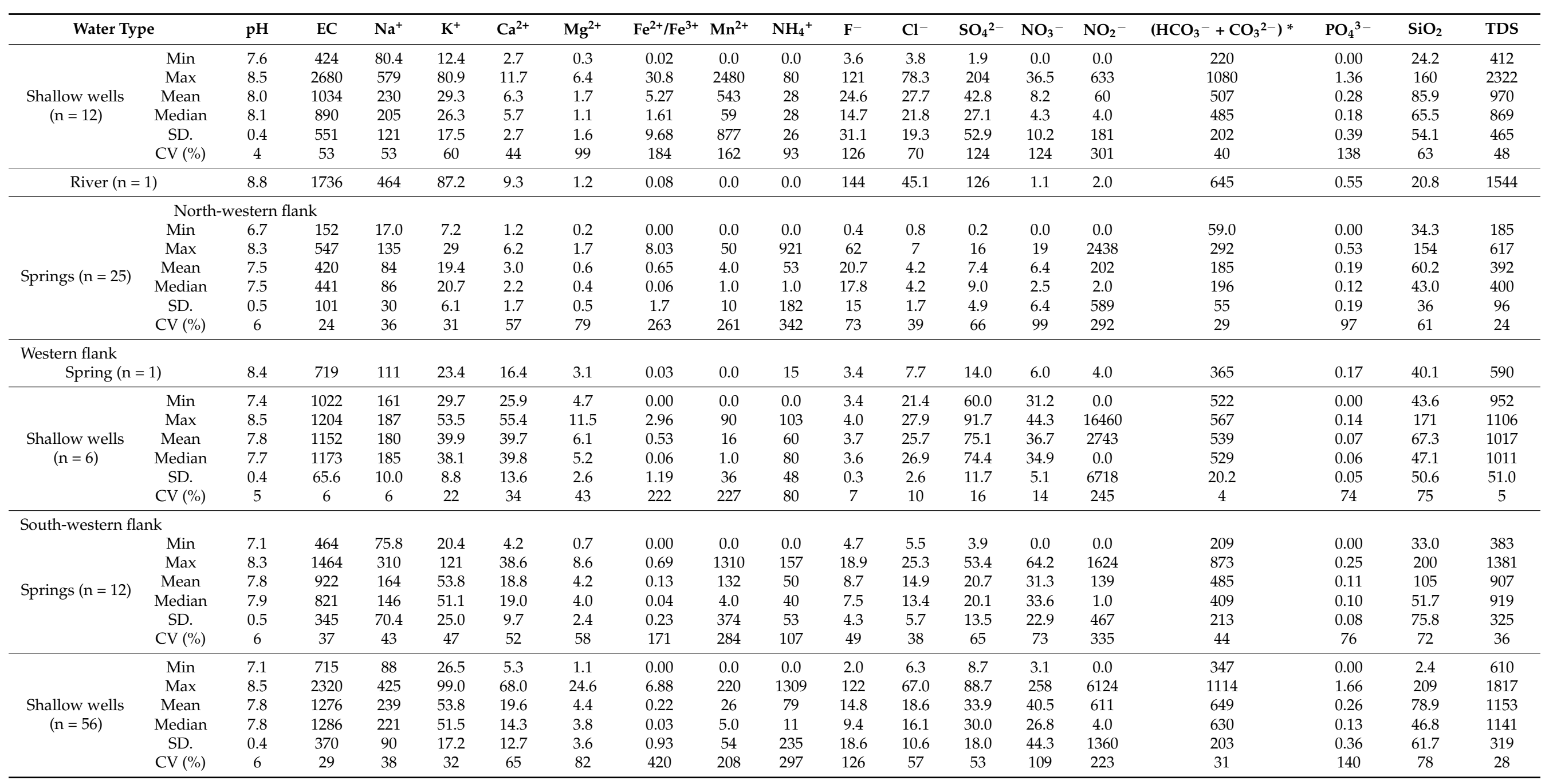


Table 2. Cont.

\begin{tabular}{|c|c|c|c|c|c|c|c|c|c|c|c|c|c|c|c|c|c|c|c|}
\hline \multicolumn{2}{|c|}{ Water Type } & $\mathrm{pH}$ & EC & $\mathrm{Na}^{+}$ & $\mathrm{K}^{+}$ & $\mathrm{Ca}^{2+}$ & $\mathrm{Mg}^{2+}$ & $\mathrm{Fe}^{2+} / \mathrm{Fe}^{3+}$ & $\mathrm{Mn}^{2+}$ & $\mathrm{NH}_{4}{ }^{+}$ & $\mathbf{F}^{-}$ & $\mathrm{Cl}^{-}$ & $\mathrm{SO}_{4}{ }^{2-}$ & $\mathrm{NO}_{3}^{-}$ & $\mathrm{NO}_{2}^{-}$ & $\left(\mathrm{HCO}_{3}^{-}+\mathrm{CO}_{3}^{2-}\right)^{*}$ & $\mathrm{PO}_{4}{ }^{3-}$ & $\mathrm{SiO}_{2}$ & TDS \\
\hline \multirow{6}{*}{$\begin{array}{l}\text { Deep wells } \\
\quad(\mathrm{n}=3)\end{array}$} & Min & 7.5 & 606 & 105 & 21.9 & 7.9 & 1.6 & 0.03 & 0.0 & 0.0 & 3.8 & 5.7 & 7.3 & 0.0 & 1.0 & 310 & 0.53 & 40.4 & 508 \\
\hline & Max & 8.0 & 769 & 133 & 33.4 & 25.5 & 6.9 & 0.05 & 6.0 & 71 & 7.8 & 8.8 & 21.8 & 9.1 & 54 & 457 & 0.65 & 51.9 & 742 \\
\hline & Mean & 7.7 & 700 & 120 & 27.7 & 19.3 & 4.8 & 0.04 & 4.0 & 24 & 5.4 & 7.5 & 16.2 & 5.4 & 20 & 400 & 0.58 & 46.8 & 653 \\
\hline & Median & 7.6 & 726 & 121 & 27.7 & 24.5 & 6.0 & 0.05 & 5.0 & 2.0 & 4.6 & 7.9 & 19.5 & 7.2 & 4.0 & 433 & 0.54 & 48.1 & 710 \\
\hline & SD. & 0.3 & 84.5 & 14.0 & 5.8 & 9.9 & 2.8 & 0.01 & 3.0 & 40 & 2.1 & 1.6 & 7.8 & 4.8 & 30 & 78.9 & 0.06 & 5.9 & 127 \\
\hline & CV (\%) & 4 & 12 & 12 & 21 & 51 & 58 & 35 & 88 & 168 & 39 & 21 & 48 & 88 & 153 & 20 & 11 & 13 & 19 \\
\hline
\end{tabular}




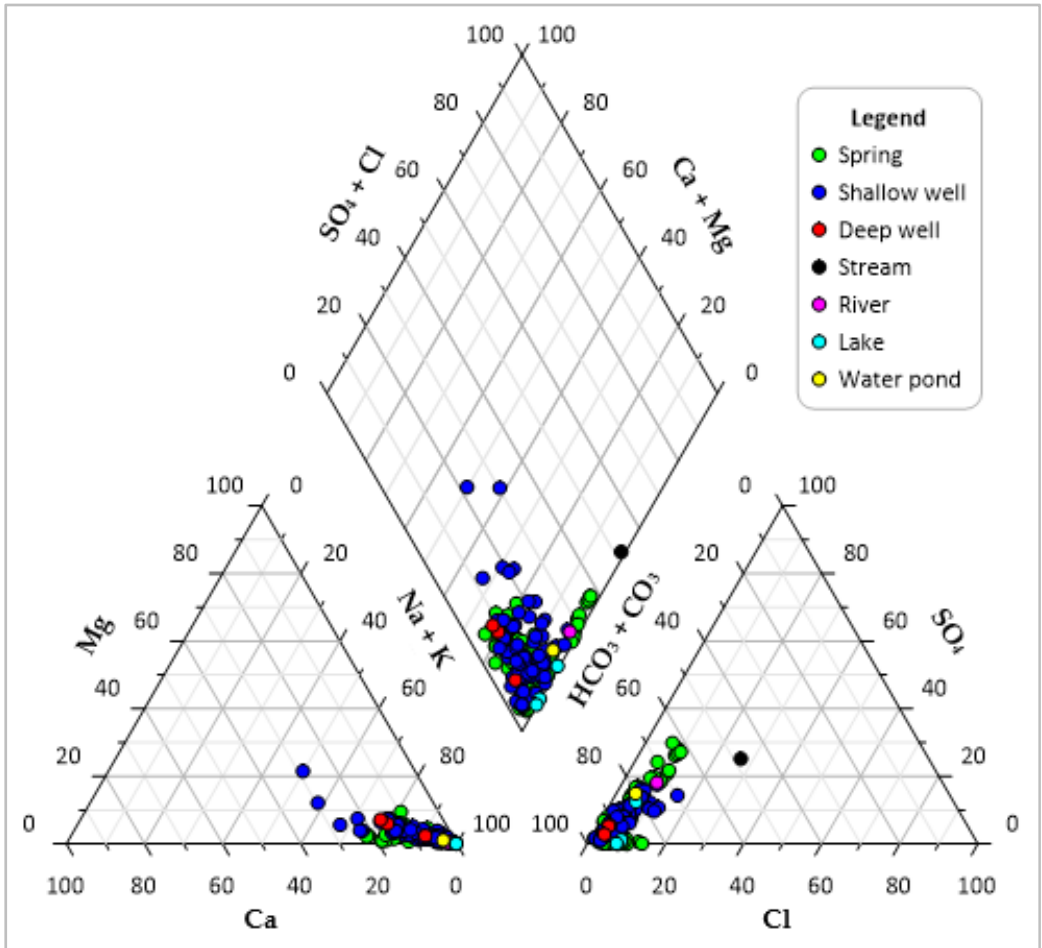

Figure 5. Piper diagram showing different water samples taken from springs, shallow wells, deep wells, stream, river, lakes, and water ponds.

\subsection{Physicochemical Characteristics and Conceptual Groundwater Flow Model}

In 175 groundwater samples, $\mathrm{pH}$ values range from 6.7 to 8.6 with an average of 7.8 and a median of 7.8 , indicating alkaline groundwater. In the six surface water samples, $\mathrm{pH}$ values range from 8.8 to 10.1 with an average of 9.4 and a median of 9.3 , also, indicating alkaline water. Figure 6 shows the spatial distribution of TDS in the study area with a clear increasing trend from the higher elevations towards the lower elevations. On the eastern flank, below the ash cone, water samples from the springs show $\mathrm{pH}$ values between 7.1 and 8.6 with an average of 7.8 and a median of 7.8. Their EC values range from $105 \mu \mathrm{S} / \mathrm{cm}$ (at reference temperature of $25^{\circ} \mathrm{C}$ ) to $4590 \mu \mathrm{S} / \mathrm{cm}$ (hydrothermal spring) with an average of $759 \mu \mathrm{S} / \mathrm{cm}$ and a median of $239 \mu \mathrm{S} / \mathrm{cm}$, while their TDS values range from 117 to $4214 \mathrm{mg} / \mathrm{L}$ with an average of $703 \mathrm{mg} / \mathrm{L}$ and a median of $238 \mathrm{mg} / \mathrm{L}$. Despite being at higher elevations in the recharge area, water samples from the two hydrothermal springs (S42-Small Njekukumia and S43-Big Njekukumia) near the ash cone are highly mineralised (average: $3642 \mathrm{mg} / \mathrm{L}$ ) compared to the surrounding springs, which show low mineralisation (average: $203 \mathrm{mg} / \mathrm{L}$; they are warmer (average temperature: $20.0^{\circ} \mathrm{C}$ ) compared to the surrounding springs (average temperature: $13.3^{\circ} \mathrm{C}$ )), which indicates they are originating from a deep source. In addition, the water sample from the Njekukumia stream (at point STP9), which receives its water from the hydrothermal springs, shows high mineralisation and $\mathrm{pH}(\mathrm{pH}=9.1, \mathrm{EC}=4390 \mu \mathrm{S} / \mathrm{cm}, \mathrm{TDS}=3540 \mathrm{mg} / \mathrm{L})$. The two springs (S44-Small Tululusia and S45-Big Tululusia) that lie on the same line below the hydrothermal springs show significant mineralisation (average: $1174 \mathrm{mg} / \mathrm{L}$ ). This suggests that their mineralisation might be influenced by the infiltrated water from the hydrothermal springs or derived from the same source. 


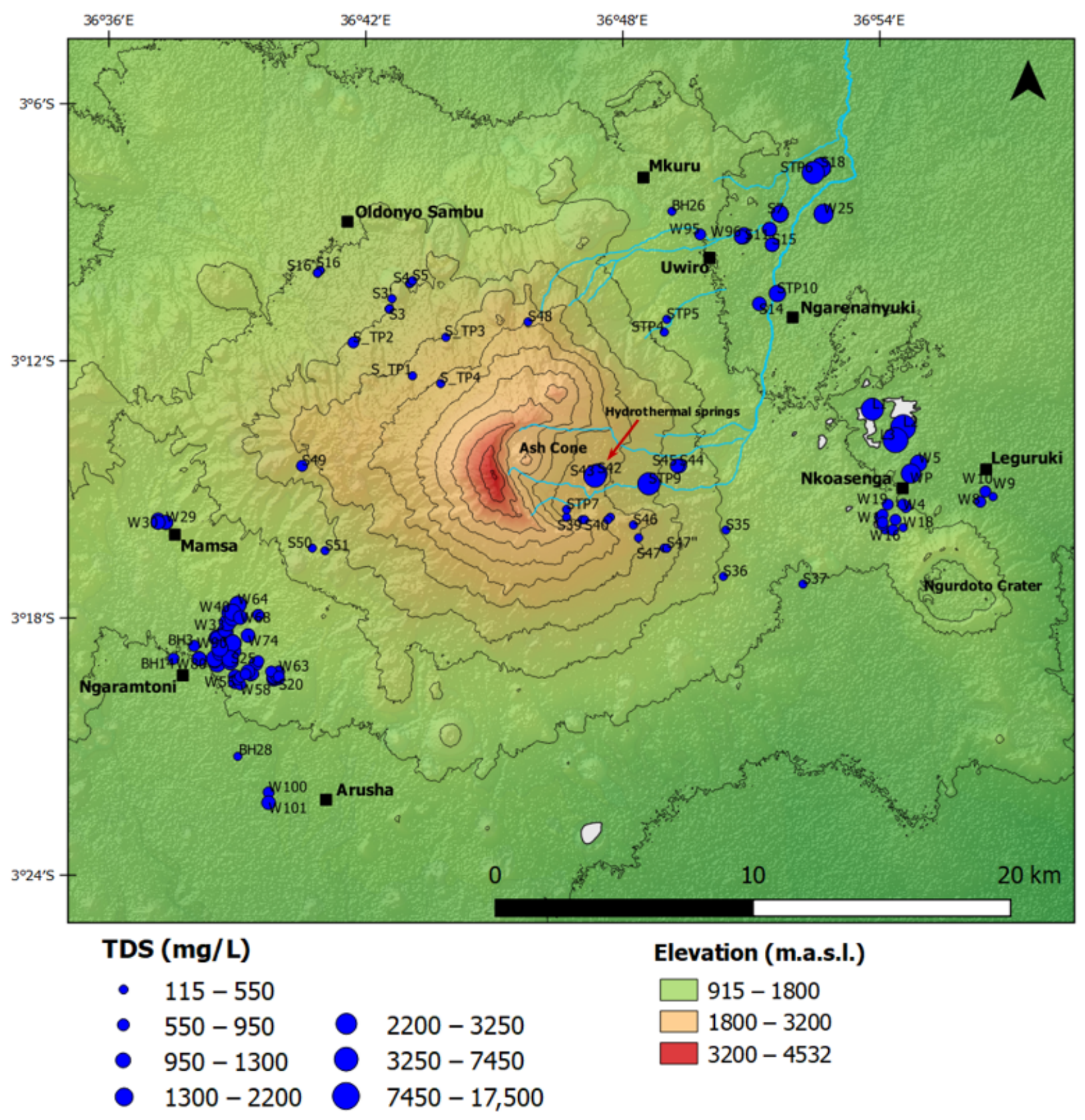

Figure 6. Spatial distribution of TDS in the study area with a clear increasing trend from the higher elevations towards the lower elevations (Labels: S, S_TP and STP—Spring (except STP9—Stream and STP10—River), W-Well, BH—Borehole, WP-Water pond, L-Lake).

At lower elevations, in the discharge area, surface water samples from the three lakes (L1-Small Momella lake, L2 - Big Momella lake, and L3-Lake Rishateni) show $\mathrm{pH}$ values ranging from 9.5 to 10.1 with an average of 9.8 and a median of 9.9 , while their EC values range from 8630 to $19,820 \mu \mathrm{S} / \mathrm{cm}$ with an average of $15,340 \mu \mathrm{S} / \mathrm{cm}$ and a median of $17,570 \mu \mathrm{S} / \mathrm{cm}$, and their TDS values range from 7438 to $17495 \mathrm{mg} / \mathrm{L}$ with an average of $13,541 \mathrm{mg} / \mathrm{L}$ and a median of $15,691 \mathrm{mg} / \mathrm{L}$. The lakes are highly mineralised compared to other water samples. These lakes are closed basin lakes (no water in, no water out); therefore, a longer water residence time and evapoconcentration lead to high mineralisation of these waters.

Figure 7 shows a simplified groundwater flow conceptual model for the northeastern flank of Mount Meru showing different flow systems: local, intermediary, and regional $[31,32]$. The model was developed based on hydrogeochemical processes, ground- 
water mineralisation, spring settings, and groundwater level in the shallow wells. The model suggests the influence of the volcanic gases in the groundwater chemistry of the two hydrothermal springs (S42 and S43) and the two springs from the discharge area (S18 and STP6), which are flowing from the deepest flow line [33-35]. The model shows the increase of groundwater mineralisation with water residence times. The longer the flow path, the longer the residence time, hence high mineralisation.

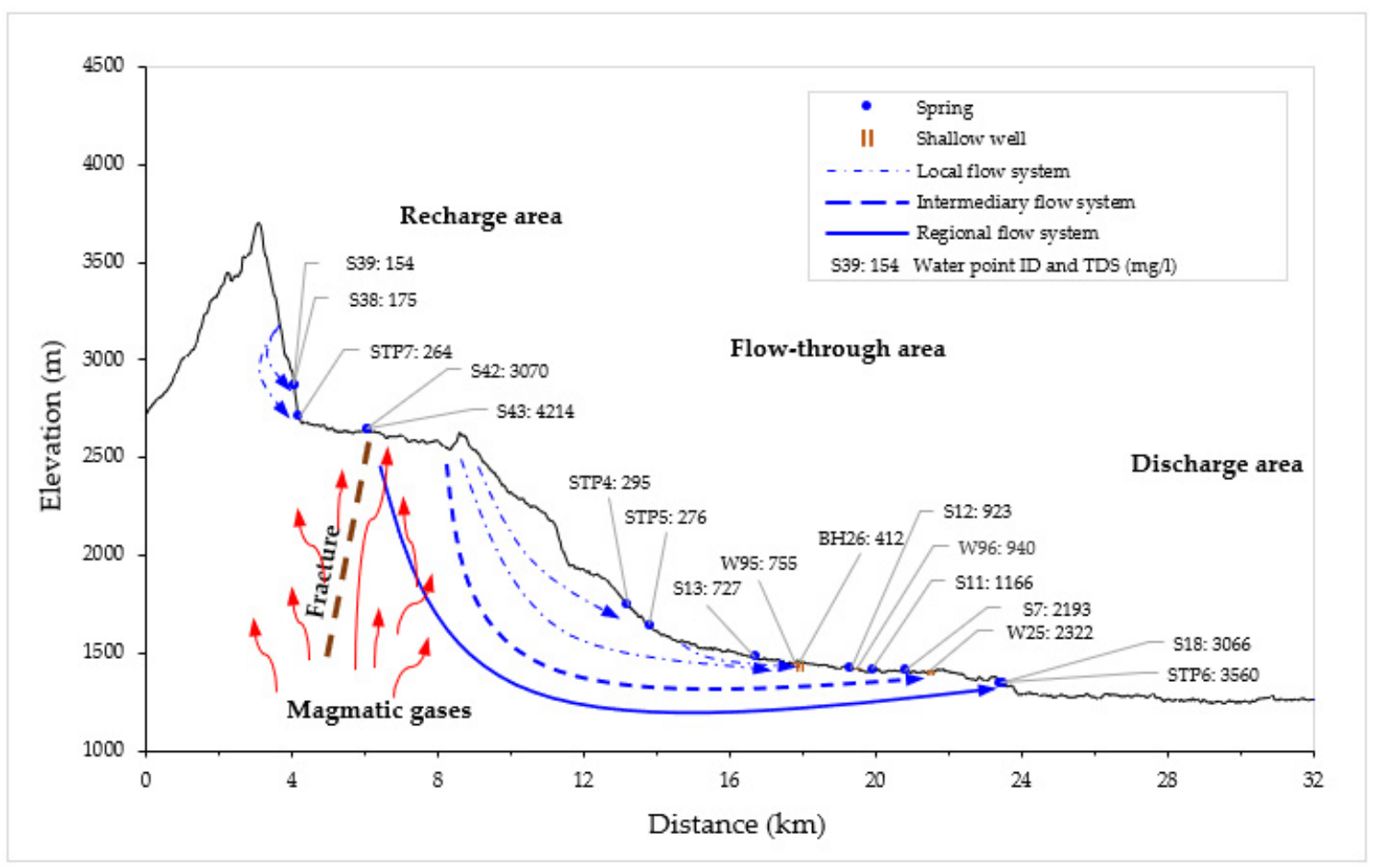

Figure 7. Simplified groundwater flow conceptual model for the northeastern flank of Mount Meru, suggesting the influence of the volcanic gases in the groundwater chemistry and also showing the increase of groundwater mineralisation with water residence times.

On the far east of the eastern flank, on the northern flank of Ngurdoto crater, at Nkoasenga, water samples from the two springs found in the area show that spring S1 at elevation of $1560 \mathrm{~m}$ is less mineralised $(\mathrm{pH}=7.2, \mathrm{EC}=632 \mu \mathrm{S} / \mathrm{cm}, \mathrm{TDS}=573 \mathrm{mg} / \mathrm{L})$ compared to S2 at lower elevation of $1483 \mathrm{~m}(\mathrm{pH}=7.6, \mathrm{EC}=919 \mu \mathrm{S} / \mathrm{cm}$, TDS $=789 \mathrm{mg} / \mathrm{L})$, indicating that the groundwater mineral content progressively increases along the flow path with increasing residence time, long residence times favouring prolonged water-rock interaction. The trend is also observed in shallow wells where wells at high elevations (average: $1586 \mathrm{~m}$ ) show low mineralisation (average values: $\mathrm{pH}=7.7, \mathrm{EC}=621 \mu \mathrm{S} / \mathrm{cm}$, TDS $=605 \mathrm{mg} / \mathrm{L}$ ) compared to wells at low elevations (average: $1491 \mathrm{~m}$ ), which show significant mineralisation (average values: $\mathrm{pH}=8.2, \mathrm{EC}=1221 \mu \mathrm{S} / \mathrm{cm}$, TDS $=1118 \mathrm{mg} / \mathrm{L}$ ). The only surface water sample WP from a water pond which is at lower elevation of $1429 \mathrm{~m}$ is highly mineralised $(\mathrm{pH}=9.2, \mathrm{EC}=4310 \mu \mathrm{S} / \mathrm{cm}, \mathrm{TDS}=3237 \mathrm{mg} / \mathrm{L})$ compared to other samples; this is attributed to longer water residence time and evapoconcentration. In Leguruki, shallow wells at lower elevation of $1354 \mathrm{~m}$ show low mineralisation (average values: $\mathrm{pH}=7.7, \mathrm{EC}=743 \mu \mathrm{S} / \mathrm{cm}, \mathrm{TDS}=666 \mathrm{mg} / \mathrm{L}$ ), similar mineralisation as water samples from high elevations in Nkoasenga. The low mineralisation of these wells, despite being at lower elevations, suggests shorter water residence times. These shorter residence times suggest that there are different local flow systems in the area.

Table 3 shows the average values of $\mathrm{pH}, \mathrm{EC}$, and TDS in the water samples from different elevations and different well depths on the northeastern, northwestern, western, and southwestern flank of Mount Meru. On the northeastern flank, at Ngarenanyuki, Uwiro, and Mkuru, both springs and wells also show a similar trend of progressive 
mineralisation of the groundwater along the flow paths. On average, on the northwestern flank, at Oldonyo Sambu, there is progressive mineralisation of the groundwater from elevation of $2567 \mathrm{~m}$ (average TDS: $242 \mathrm{mg} / \mathrm{L}$ ) to $2084 \mathrm{~m}$ (average TDS: $410 \mathrm{mg} / \mathrm{L}$ ); then, the mineralisation remains comparable towards the lower elevations (average TDS: $446 \mathrm{mg} / \mathrm{L}$ at $1838 \mathrm{~m}$ elevation). This suggests that the groundwater is flowing through fractures between 2084 and $1838 \mathrm{~m}$ elevations or is due to a local flow system in the area. On the western flank, at Mamsa, there is also clear progressive mineralisation of the groundwater along the flow path as the spring at higher elevation of $2240 \mathrm{~m}$ shows low mineralisation (TDS: $590 \mathrm{mg} / \mathrm{L}$ ) compared to shallow wells at lower elevation of $1649 \mathrm{~m}$ (average TDS: $1017 \mathrm{mg} / \mathrm{L}$ ). On the southwestern flank, at Ngaramtoni and near Arusha town, also the similar trend of progressive mineralisation of the groundwater from the upstream to the downstream is observed in both springs and wells but with some exceptions in some wells. Despite being at lower elevation of 1379 m, two shallow wells (W100 and W101) show low mineralisation (average TDS: $893 \mathrm{mg} / \mathrm{L}$ ) compared to shallow wells at intermediate elevation of $1548 \mathrm{~m}$ (average TDS: $1188 \mathrm{mg} / \mathrm{L}$ ), also, this suggests shorter water residence times, due to different local flow systems in the area. In addition, despite being at lower elevations, deep wells show low mineralisation (average TDS: $653 \mathrm{mg} / \mathrm{L}$ ) compared to all shallow wells (range of average TDS: 744-1188 mg/L); this suggests that these are deep circulating waters that have undergone deep infiltration in the recharge area at higher elevations, possibly through fractures and faults. The low mineralisation in the deep circulating groundwater compared to the shallow one can be attributed to slow weathering and dissolution of aluminosilicate minerals in the weathered fractured lava composing the deep aquifer compared to the pyroclastic deposits that form the composition of the shallow aquifer.

Table 3. Average values of $\mathrm{pH}, \mathrm{EC}$, and TDS in the water samples from different elevations and different well depths on the northeastern, northwestern, western, and southwestern flank of Mount Meru.

\begin{tabular}{|c|c|c|c|c|c|c|c|}
\hline Region & Water Source & $\begin{array}{l}\text { Number of } \\
\text { Samples }\end{array}$ & $\begin{array}{c}\text { Average } \\
\text { Elevation (m) }\end{array}$ & $\begin{array}{c}\text { Average Well } \\
\text { Depth (m) }\end{array}$ & Average $\mathrm{pH}$ & $\begin{array}{c}\text { Average EC } \\
(\mu \mathrm{S} / \mathrm{cm} \text { at } \\
\left.25^{\circ} \mathrm{C}\right)\end{array}$ & $\begin{array}{l}\text { Average TDS } \\
(\mathrm{mg} / \mathrm{L})\end{array}$ \\
\hline \multirow{8}{*}{$\begin{array}{l}\text { North-eastern } \\
\text { flank }\end{array}$} & \multirow{4}{*}{ Springs } & 2 & 1705 & & 6.9 & 307 & 286 \\
\hline & & 13 & 1430 & & 7.6 & 998 & 916 \\
\hline & & 4 & 1402 & & 8.1 & 1915 & 1819 \\
\hline & & 8 & 1332 & & 8.2 & 3449 & 2984 \\
\hline & \multirow{3}{*}{ Shallow wells } & 1 & 1551 & 48 & 7.7 & 424 & 412 \\
\hline & & 10 & 1452 & 8 & 8.0 & 930 & 891 \\
\hline & & 1 & 1399 & 27 & 8.5 & 2680 & 2322 \\
\hline & River & 1 & 1443 & & 8.8 & 1736 & 1544 \\
\hline \multirow{3}{*}{$\begin{array}{c}\text { North-western } \\
\text { flank }\end{array}$} & \multirow{3}{*}{ Springs } & 4 & 2567 & & 7.9 & 214 & 242 \\
\hline & & 15 & 2084 & & 7.6 & 444 & 410 \\
\hline & & 6 & 1838 & & 7.1 & 496 & 446 \\
\hline \multirow{2}{*}{ Western flank } & Spring & 1 & 2240 & & 8.4 & 719 & 590 \\
\hline & Shallow wells & 6 & 1649 & 44 & 7.8 & 1152 & 1017 \\
\hline \multirow{6}{*}{$\begin{array}{l}\text { South-western } \\
\text { flank }\end{array}$} & \multirow{2}{*}{ Springs } & 2 & 1921 & & 7.9 & 465 & 386 \\
\hline & & 10 & 1566 & & 7.8 & 1014 & 1012 \\
\hline & \multirow{3}{*}{ Shallow wells } & 3 & 1631 & 16 & 7.3 & 833 & 744 \\
\hline & & 51 & 1548 & 19 & 7.9 & 1310 & 1188 \\
\hline & & 2 & 1379 & 6 & 8.2 & 1068 & 893 \\
\hline & Deep wells & 3 & 1467 & 151 & 7.7 & 700 & 653 \\
\hline
\end{tabular}

\subsection{Major and Minor Ions Origin}

Table 4 shows the correlation matrix between the main hydrogeochemical parameters. The significant strong positive correlations are highlighted in green colour. The significant strong positive correlation between total alkalinity $\left(\mathrm{HCO}_{3}{ }^{-}+\mathrm{CO}_{3}{ }^{2-}\right)$, alkaline elements $\left(\mathrm{Na}^{+}\right.$and $\left.\mathrm{K}^{+}\right), \mathrm{SO}_{4}{ }^{2-}$, and $\mathrm{Cl}^{-}$suggests that they are released in groundwater 
by simultaneously occurring hydrogeochemical processes. The strong positive correlation of TDS with $\mathrm{Na}^{+}, \mathrm{K}^{+}, \mathrm{HCO}_{3}{ }^{-}+\mathrm{CO}_{3}{ }^{2-}, \mathrm{SO}_{4}{ }^{2-}$, and $\mathrm{Cl}^{-}$indicates that the concentration of these elements progressively increases together with the mineralisation of the groundwater along the groundwater flow path in response to the main hydrogeochemical processes [29]. The strong positive correlation of $\mathrm{Cl}^{-}$with $\mathrm{Na}^{+}, \mathrm{K}^{+}, \mathrm{HCO}_{3}{ }^{-}+\mathrm{CO}_{3}{ }^{2-}$, and $\mathrm{SO}_{4}{ }^{2-}$ suggests the evapoconcentration along the flow path, the localised dissolution of evaporitic salts such as halite $(\mathrm{NaCl})$, sylvite $(\mathrm{KCl})$, gypsum $\left(\mathrm{CaSO}_{4} \cdot 2 \mathrm{H}_{2} \mathrm{O}\right)$, anhydrite $\left(\mathrm{CaSO}_{4}\right)$, thenardite $\left(\mathrm{Na}_{2} \mathrm{SO}_{4}\right)$, and mirabilite $\left(\mathrm{Na}_{2} \mathrm{SO}_{4} \cdot 10 \mathrm{H}_{2} \mathrm{O}\right)[29,36]$, and the admixture of volcanic gases (which are containing lots of $\mathrm{CO}_{2}, \mathrm{SO}_{2}, \mathrm{HCl}, \mathrm{HF}$ ) as Mount Meru is an active volcano [33-35]. The significant moderate positive correlations of $\mathrm{F}^{-}$with $\mathrm{Na}^{+}$and $\mathrm{K}^{+}$indicate that the progressive increase of $\mathrm{F}^{-}$goes parallel with the increase in alkaline elements (suggesting progressive rock-water interaction), whereas the significant weak negative correlations of $\mathrm{F}^{-}$with $\mathrm{Ca}^{2+}$ and $\mathrm{Mg}^{2+}$ indicate that the progressive increase of $\mathrm{F}^{-}$goes parallel with the decrease in alkaline earth elements along the groundwater flow paths, through precipitation of carbonate minerals: aragonite, calcite, and dolomite. The high concentrations of $\mathrm{HCO}_{3}{ }^{-}+\mathrm{CO}_{3}{ }^{2-}, \mathrm{SO}_{4}{ }^{2-}, \mathrm{Cl}^{-}$, and $\mathrm{F}^{-}$in the two hydrothermal springs suggest that the volcanic emissions are responsible for their composition.

Table 4. Correlation matrix for all water samples $(n=181)$. Strong correlations are highlighted in green colour.

\begin{tabular}{|c|c|c|c|c|c|c|c|c|c|c|c|}
\hline & $\mathrm{Na}^{+}$ & $\mathbf{K}^{+}$ & $\mathrm{Ca}^{2+}$ & $\mathrm{Mg}^{2+}$ & $\mathrm{HCO}_{3}^{-}+\mathrm{CO}_{3}^{2-}$ & $\mathrm{SO}_{4}{ }^{2-}$ & $\mathrm{Cl}^{-}$ & $\mathbf{F}^{-}$ & $\mathrm{NO}_{3}{ }^{-}$ & $\mathrm{SiO}_{2}$ & TDS \\
\hline $\mathrm{Na}^{+}$ & 1 & & & & & & & & & & \\
\hline $\mathrm{K}^{+}$ & $0.803^{* *}$ & 1 & & & & & & & & & \\
\hline $\mathrm{Ca}^{2+}$ & $0.355^{* *}$ & $0.464^{* *}$ & 1 & & & & & & & & \\
\hline $\mathrm{Mg}^{2+}$ & $0.445^{* *}$ & $0.593^{* *}$ & $0.855^{* *}$ & 1 & & & & & & & \\
\hline $\mathrm{HCO}_{3}{ }^{-}+\mathrm{CO}_{3}{ }^{2-}$ & $0.946^{* *}$ & $0.831^{* *}$ & 0.502 ** & $0.574^{* *}$ & 1 & & & & & & \\
\hline $\mathrm{SO}_{4}{ }^{2-}$ & $0.782 * *$ & $0.707^{* *}$ & $0.469^{* *}$ & $0.594^{* *}$ & $0.752 * *$ & 1 & & & & & \\
\hline $\mathrm{Cl}^{-}$ & $0.827 * *$ & $0.737^{* *}$ & $0.478 * *$ & $0.551^{* *}$ & $0.805^{* *}$ & $0.823 * *$ & 1 & & & & \\
\hline $\mathrm{F}^{-}$ & 0.611 ** & $0.421^{* *}$ & $-0.267^{* *}$ & -0.179 * & $0.467^{* *}$ & $0.335^{* *}$ & $0.336^{* *}$ & 1 & & & \\
\hline $\mathrm{NO}_{3}{ }^{-}$ & $0.393^{* *}$ & $0.479 * *$ & $0.545^{* *}$ & $0.550 * *$ & $0.442 * *$ & $0.463^{* *}$ & $0.428^{* *}$ & 0.011 & 1 & & \\
\hline $\mathrm{SiO}_{2}$ & -0.087 & 0.016 & $0.229^{* *}$ & $0.274^{* *}$ & -0.048 & -0.044 & -0.016 & $-0.180 *$ & $0.269 * *$ & 1 & \\
\hline TDS & $0.969 * *$ & $0.870^{* *}$ & $0.472 * *$ & $0.563^{* *}$ & $0.964^{* *}$ & $0.795^{* *}$ & $0.853^{* *}$ & $0.518^{* *}$ & $0.473 * *$ & 0.024 & 1 \\
\hline
\end{tabular}

** Correlation is significant at the 0.01 level (2-tailed). ${ }^{*}$ Correlation is significant at the 0.05 level (2-tailed).

\subsubsection{Eastern and Northeastern Flanks}

The concentration of $\mathrm{Na}^{+}$in groundwater varies between $15.1 \mathrm{mg} / \mathrm{L}$ (spring water from the recharge area) and $1123 \mathrm{mg} / \mathrm{L}$ (hydrothermal spring water). The spatial distribution of $\mathrm{Na}^{+}$shows an increasing trend from the higher elevations where the springs from the recharge areas show lower concentrations (average: $29.7 \mathrm{mg} / \mathrm{L}$ ) towards the lower elevations (flow-through and discharge areas), where water samples show higher concentrations (springs: average $393 \mathrm{mg} / \mathrm{L}$; wells: average $230 \mathrm{mg} / \mathrm{L}$ ), indicating a progressive increase along groundwater flow paths. The two hydrothermal springs show higher $\mathrm{Na}^{+}$concentrations (average: $1011 \mathrm{mg} / \mathrm{L}$ ); they may contribute high $\mathrm{Na}^{+}$concentrations in the shallow aquifer on these flanks. In all 57 groundwater samples from these flanks, the average concentrations of $\mathrm{Na}^{+}, \mathrm{K}^{+}, \mathrm{Ca}^{2+}$, and $\mathrm{Mg}^{2+}$ in $\mathrm{mg} / \mathrm{L}$ are 293, 46.4, 9.7, and 2.5 respectively, suggesting that the contribution of Na-K-bearing minerals in releasing cations in the groundwater is more important than that of $\mathrm{Ca}-\mathrm{Mg}$-bearing minerals.

The concentration of total alkalinity $\left(\mathrm{HCO}_{3}{ }^{-}+\mathrm{CO}_{3}{ }^{2-}\right)$ in groundwater varies between $44.5 \mathrm{mg} / \mathrm{L} \mathrm{HCO}_{3}{ }^{-}$(spring water from the recharge area) and $2170 \mathrm{mg} / \mathrm{L} \mathrm{HCO}_{3}{ }^{-}$ (hydrothermal spring water). The total alkalinity increases from the recharge area where springs show lower concentrations (average: $103 \mathrm{mg} / \mathrm{L} \mathrm{HCO}_{3}{ }^{-}$) towards the discharge areas where water samples show higher concentrations (springs: average $820 \mathrm{mg} / \mathrm{L} \mathrm{HCO}_{3}{ }^{-}$; wells: average $507 \mathrm{mg} / \mathrm{L} \mathrm{HCO}_{3}{ }^{-}$). This indicates that the concentration of the total alkalinity progressively increases along the groundwater flow path with increasing residence time as the result of the dissolution of $\mathrm{CO}_{2}(\mathrm{~g})$ in groundwater that forms $\mathrm{H}_{2} \mathrm{CO}_{3}$ that causes extensive aluminosilicate dissolution, raising $\mathrm{HCO}_{3}{ }^{-}$in the groundwater; at high $\mathrm{pH}$, the $\mathrm{HCO}_{3}{ }^{-}$transforms to $\mathrm{CO}_{3}{ }^{2-}$. The $\mathrm{CO}_{2}(\mathrm{~g})$ comes from the admixture of volcanic gases [33-35], the atmosphere, the respiration of microorganisms in the soil zone, and the aerobic and anaerobic decomposition of organic matter in infiltrating water [29]. 
The two hydrothermal springs show the highest $\mathrm{HCO}_{3}{ }^{-}+\mathrm{CO}_{3}{ }^{2-}$ concentrations (average: $1728 \mathrm{mg} / \mathrm{L} \mathrm{HCO}_{3}{ }^{-}$); this indicates that volcanic emissions are here contributing high $\mathrm{CO}_{2}(\mathrm{~g})$ in the groundwater; also, they may contribute high $\mathrm{HCO}_{3}{ }^{-}+\mathrm{CO}_{3}{ }^{2-}$ concentrations in the shallow aquifer on these flanks.

$\mathrm{SO}_{4}{ }^{2-}$ concentration in groundwater varies between $0.0 \mathrm{mg} / \mathrm{L}$ (spring water from the recharge area) and $499 \mathrm{mg} / \mathrm{L}$ (spring water from the discharge area). In addition, the $\mathrm{SO}_{4}{ }^{2-}$ shows a similar increasing trend from the recharge area where springs show lower concentrations (average: $0.6 \mathrm{mg} / \mathrm{L}$ ) towards the discharge areas where there are higher concentrations (springs: average $159 \mathrm{mg} / \mathrm{L}$; wells: average $42.8 \mathrm{mg} / \mathrm{L}$ ). The two hydrothermal springs show higher $\mathrm{SO}_{4}{ }^{2-}$ concentrations (average: $339 \mathrm{mg} / \mathrm{L}$ ), again pointing to volcanic emissions, which may also contribute to high $\mathrm{SO}_{4}{ }^{2-}$ concentrations in the shallow aquifer on these flanks, resulting from the reaction between $\mathrm{SO}_{2}$ and $\mathrm{H}_{2} \mathrm{O}$ in the volcanic gases [33-35].

The concentration of $\mathrm{Cl}^{-}$in groundwater varies between $1.7 \mathrm{mg} / \mathrm{L}$ (spring water from the recharge area) and $148 \mathrm{mg} / \mathrm{L}$ (hydrothermal spring water). In general, chloride behaves as a conservative element, but the spatial distribution of $\mathrm{Cl}^{-}$shows a similar increasing trend from the higher elevations where springs from the recharge area show lower concentrations (average $4.7 \mathrm{mg} / \mathrm{L}$ ) towards the lower elevations where there are higher concentrations (springs: average $41.7 \mathrm{mg} / \mathrm{L}$; wells: average $27.7 \mathrm{mg} / \mathrm{L}$ ). The hydrothermal springs show the highest $\mathrm{Cl}^{-}$concentrations (average: $124 \mathrm{mg} / \mathrm{L}$ ); this again points to volcanic emissions containing $\mathrm{HCl}[33,34]$ at depth, which may also contribute to elevated $\mathrm{Cl}^{-}$concentrations in the shallow aquifer on these flanks.

$\mathrm{F}^{-}$concentration in groundwater varies between $0.15 \mathrm{mg} / \mathrm{L}$ (spring water from the recharge area) and $301 \mathrm{mg} / \mathrm{L}$ (hydrothermal spring water). Similarly to the major parameters, the spatial distribution of $\mathrm{F}^{-}$shows an increasing trend from the higher elevations where the springs from the recharge areas show lower concentrations (average: $2.7 \mathrm{mg} / \mathrm{L}$ ) towards the lower elevations where there are higher concentrations (springs: average: $45.1 \mathrm{mg} / \mathrm{L}$; wells: average $24.6 \mathrm{mg} / \mathrm{L}$ ). The hydrothermal springs have higher $\mathrm{F}^{-}$ concentrations (average: $198 \mathrm{mg} / \mathrm{L}$ ), providing another indication of volcanic emissions at depth [33], which may also contribute high $\mathrm{F}^{-}$concentrations in the shallow aquifer on these flanks. The Njekukumia stream, which receives its water from the two hydrothermal springs is known for contributing high $\mathrm{F}^{-}$water to the Ngarenanyuki river [11]. The water sample collected at the Njekukumia stream at point STP9 $(2.5 \mathrm{~km}$ away from the hydrothermal springs) shows an extremely high $\mathrm{F}^{-}$value of $553 \mathrm{mg} / \mathrm{L}$, whereas the water sample collected at the Ngarenanyuki river at point STP10 (10 km away from STP9) shows a high $\mathrm{F}^{-}$value of $144 \mathrm{mg} / \mathrm{L}$.

$\mathrm{NO}_{3}{ }^{-}$concentration in groundwater varies between $0.0 \mathrm{mg} / \mathrm{L}$ (one spring water sample from recharge area and one well water sample from the flow-through area) and $59.1 \mathrm{mg} / \mathrm{L}$ (spring water from the discharge area). The springs from the recharge areas show lower $\mathrm{NO}_{3}{ }^{-}$concentrations (average: $2.4 \mathrm{mg} / \mathrm{L}$ ) than water samples from the lower elevations (springs: average: $14.5 \mathrm{mg} / \mathrm{L}$; wells: average: $8.2 \mathrm{mg} / \mathrm{L}$ ). The hydrothermal springs have lower $\mathrm{NO}_{3}{ }^{-}$concentrations (average: $1.7 \mathrm{mg} / \mathrm{L}$ ), showing that the hydrothermal springs are characterised by the volcanic gases, which are not containing $\mathrm{NO}_{3}{ }^{-}$, while the parameters that are high in the hydrothermal springs (total alkalinity, $\mathrm{SO}_{4}{ }^{2-}, \mathrm{Cl}^{-}, \mathrm{F}^{-}$) are derived from the volcanic emissions.

Overall, the concentration of $\mathrm{NO}_{2}{ }^{-}$is characterised by relatively low concentrations in all water samples. $\mathrm{NO}_{2}{ }^{-}$concentration in groundwater varies between $0.0 \mathrm{mg} / \mathrm{L}$ (spring and well waters) and $3.7 \mathrm{mg} / \mathrm{L}$ (spring water from the flow-through area). The springs from the recharge areas show lower $\mathrm{NO}_{2}{ }^{-}$concentrations (average: $0.001 \mathrm{mg} / \mathrm{L}$ ) than water samples from the lower elevations (springs: average $0.25 \mathrm{mg} / \mathrm{L}$; wells: average $0.06 \mathrm{mg} / \mathrm{L}$ ). The two hydrothermal springs have lower $\mathrm{NO}_{2}{ }^{-}$concentrations (average: $0.002 \mathrm{mg} / \mathrm{L}$ ).

At Ngarenanyuki, locally occurring evaporitic salt (trona $\left(\mathrm{Na}_{2} \mathrm{CO}_{3} \cdot \mathrm{NaHCO}_{3} \cdot 2 \mathrm{H}_{2} \mathrm{O}\right)$ ), an evaporite mineral locally called "magadi", is observed as an efflorescent crust during 
the dry season (Figure 8). The primary source of the "magadi" in this area is the $\mathrm{NaHCO}_{3}-$ type groundwater: during the dry season, the $\mathrm{NaHCO}_{3}$-type groundwater is concentrated at/near the surface by capillary rise and evapoconcentration, and it may precipitate to form the salt. As a result of the local presence of this salt, its dissolution during the rainy season will only have a local effect on groundwater chemistry [29]. Figure 9 shows the projection of the different water samples from these flanks in the Piper diagram.

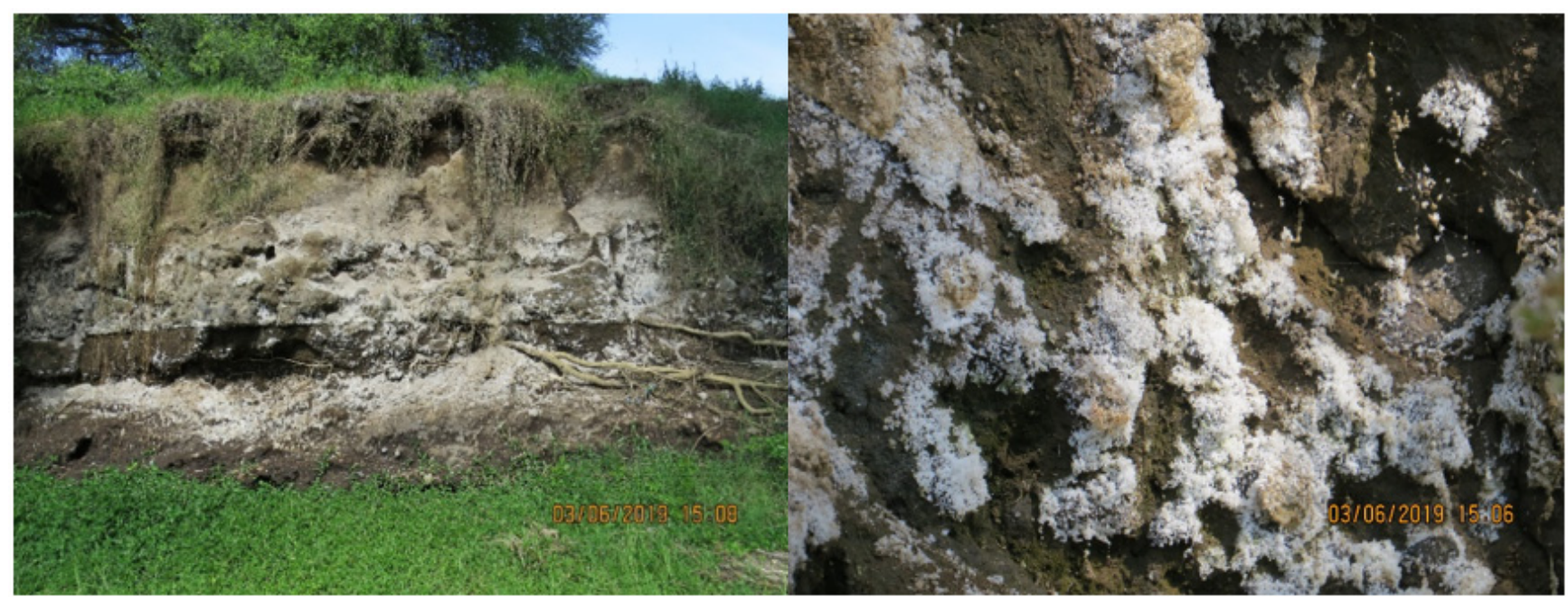

Figure 8. Pictures showing evaporitic salt "magadi" on the soil surface at Ngarenanyuki on the northeastern flank.

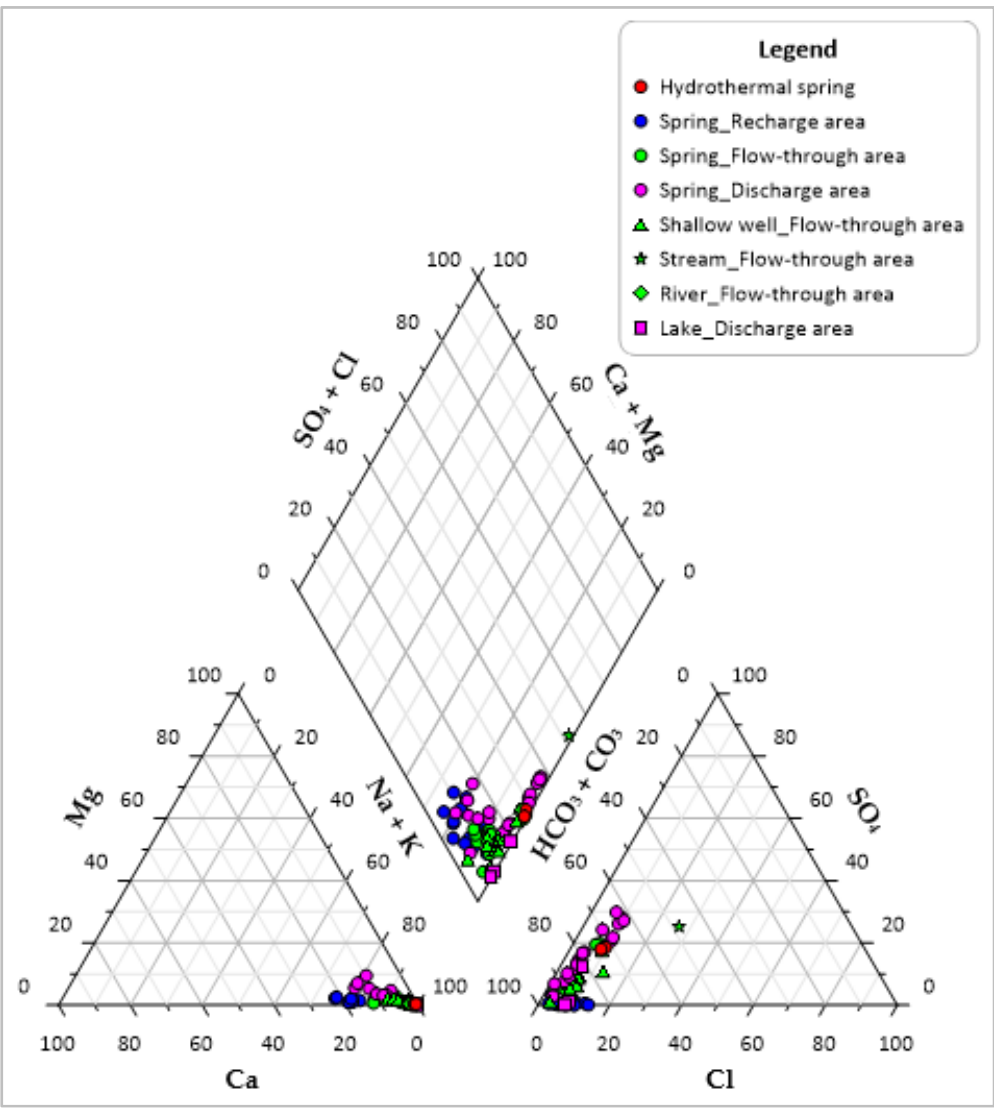

Figure 9. Piper diagram showing different water samples taken from springs, shallow wells, stream, river, and lakes on the eastern and northeastern flanks. 


\subsubsection{Far East of the Eastern Flank (Northern Flank of Ngurdoto Crater)}

The concentration of $\mathrm{Na}^{+}$in groundwater ranges from 58 to $443 \mathrm{mg} / \mathrm{L}$ (both from well waters), whereas the concentration of $\mathrm{HCO}_{3}{ }^{-}+\mathrm{CO}_{3}{ }^{2-}$ ranges from 186 to $756 \mathrm{mg} / \mathrm{L}$ $\mathrm{HCO}_{3}{ }^{-}$(both from well waters). The concentration of $\mathrm{F}^{-}$ranges from 1.0 to $134 \mathrm{mg} / \mathrm{L}$ (both from well waters). In all 15 groundwater samples from this flank, the average concentrations of $\mathrm{Na}^{+}, \mathrm{K}^{+}, \mathrm{Ca}^{2+}$, and $\mathrm{Mg}^{2+}$ in $\mathrm{mg} / \mathrm{L}$ are 135, 34.3, 11.0, and 2.3, respectively, again showing that the $\mathrm{Na-K}$-bearing minerals are dominant in releasing cations in the groundwater. Table 5 shows that, on average, water samples from both springs and wells at Nkoasenga show a progressive increase of $\mathrm{Na}^{+}, \mathrm{K}^{+}, \mathrm{HCO}_{3}{ }^{-}+\mathrm{CO}_{3}{ }^{2-}, \mathrm{SO}_{4}{ }^{2-}, \mathrm{F}^{-}$, and $\mathrm{NO}_{3}{ }^{-}$from the upstream to the downstream, whereas $\mathrm{Ca}^{2+}, \mathrm{Mg}^{2+}$, and $\mathrm{Cl}^{-}$decrease along the flow path. In Leguruki, all three water samples are from lower elevations, their low values are attributed to the local flow system in the area (see Section 3.1). Figure 10 shows the projection of the different water samples from this flank in the Piper diagram.

Table 5. Average values of major and minor ions in the water samples from different elevations on the northern flank of Ngurdoto crater $\left({ }^{*}\right.$ as $\mathrm{mg} / \mathrm{L} \mathrm{HCO}_{3}{ }^{-}$).

\begin{tabular}{|c|c|c|c|c|c|c|c|c|c|c|c|c|c|}
\hline \multirow{2}{*}{ Region } & \multirow{2}{*}{ Water Source } & \multirow{2}{*}{$\begin{array}{c}\text { Number } \\
\text { of } \\
\text { Samples }\end{array}$} & \multirow{2}{*}{$\begin{array}{c}\text { Average } \\
\text { Elevation } \\
\text { (m) }\end{array}$} & \multicolumn{10}{|c|}{ Average Concentrations $(\mathrm{mg} / \mathrm{L})$} \\
\hline & & & & $\mathrm{Na}^{+}$ & $\mathbf{K}^{+}$ & $\mathrm{Ca}^{2+}$ & $\mathrm{Mg}^{2+}$ & $\left(\mathrm{HCO}_{3}{ }^{-}+\mathrm{CO}_{3}^{2-}\right)^{*}$ & $\mathrm{SO}_{4}{ }^{2-}$ & $\mathrm{Cl}^{-}$ & $\mathbf{F}^{-}$ & $\mathrm{NO}_{3}{ }^{-}$ & $\mathrm{NO}_{2}{ }^{-}$ \\
\hline \multirow{4}{*}{ Nkoasenga } & Snrings & 1 & 1560 & 106 & 26.2 & 14.0 & 2.4 & 334 & 19.8 & 13.4 & 2.6 & 10.0 & 0.002 \\
\hline & springs & 1 & 1483 & 171 & 42.8 & 2.4 & 0.4 & 478 & 25.7 & 3.3 & 10.7 & 23.5 & 0.078 \\
\hline & & 7 & 1586 & 94 & 27.5 & 12.4 & 2.4 & 295 & 22.6 & 9.5 & 3.5 & 11.6 & 0.347 \\
\hline & Shallow wells & 3 & 1491 & 251 & 50.8 & 4.5 & 1.2 & 508 & 35.6 & 10.9 & 68.6 & 44.3 & 0.000 \\
\hline Leguruki & Shallow wells & 3 & 1354 & 111 & 33.5 & 16.2 & 3.7 & 346 & 29.9 & 11.8 & 4.6 & 26.0 & 0.002 \\
\hline
\end{tabular}

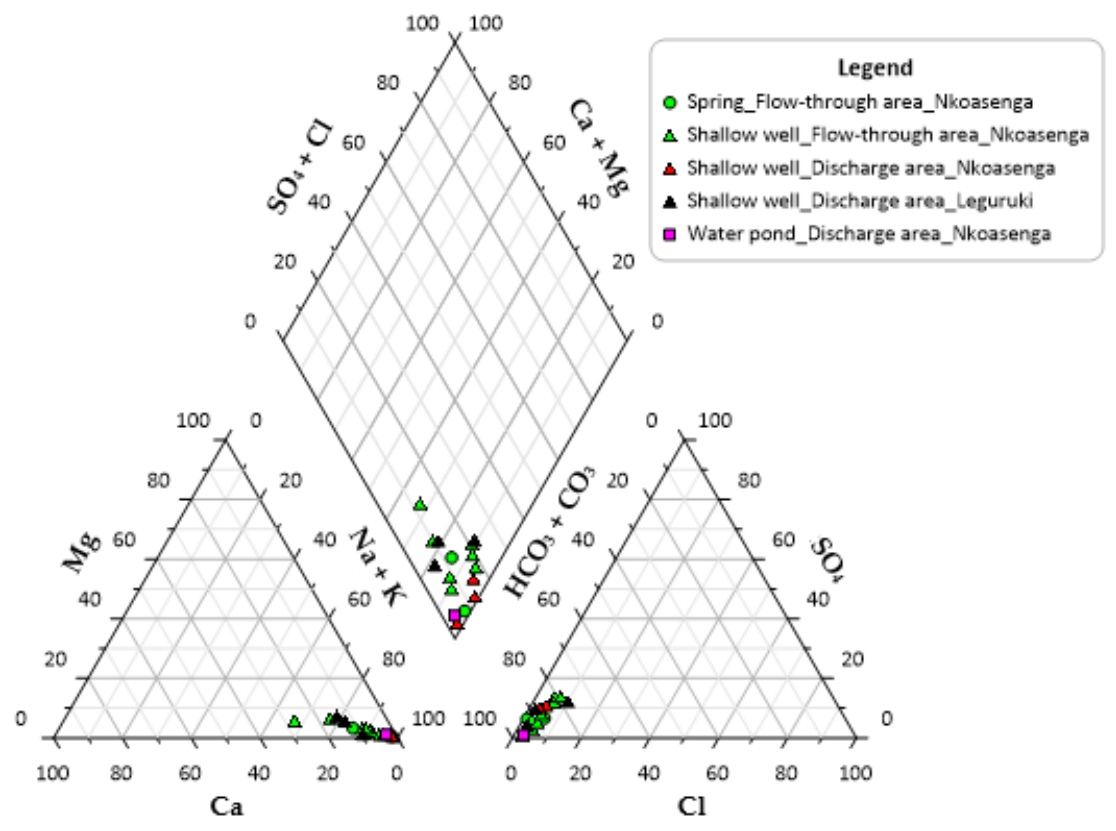

Figure 10. Piper diagram showing different water samples taken from springs, shallow wells, and water pond on the northern flank of Ngurdoto crater.

\subsubsection{Northwestern and Western Flanks}

On the northwestern flank, all water samples are from springs, the concentration of $\mathrm{Na}^{+}$in groundwater ranges from 17.0 to $135 \mathrm{mg} / \mathrm{L}$, whereas the concentration of $\mathrm{HCO}_{3}{ }^{-}+\mathrm{CO}_{3}{ }^{2-}$ ranges from 59.0 to $292 \mathrm{mg} / \mathrm{L} \mathrm{HCO}_{3}{ }^{-}$. The concentration of $\mathrm{F}^{-}$ranges from 0.4 to $61.7 \mathrm{mg} / \mathrm{L}$. In all 25 groundwater samples from this flank, the average concentrations of $\mathrm{Na}^{+}, \mathrm{K}^{+}, \mathrm{Ca}^{2+}$, and $\mathrm{Mg}^{2+}$ in $\mathrm{mg} / \mathrm{L}$ are 83.9, 19.4, 3.0, and 0.6, respectively. Again, this shows that the Na-K-bearing minerals are dominant in releasing cations in the groundwater. On the western flank, the concentration of $\mathrm{Na}^{+}$ranges from $111 \mathrm{mg} / \mathrm{L}$ 
(spring water) to $187 \mathrm{mg} / \mathrm{L}$ (well water), whereas the concentration of $\mathrm{HCO}_{3}{ }^{-}+\mathrm{CO}_{3}{ }^{2-}$ ranges from $365 \mathrm{mg} / \mathrm{L} \mathrm{HCO}_{3}{ }^{-}$(spring water) to $567 \mathrm{mg} / \mathrm{L} \mathrm{HCO}_{3}{ }^{-}$(well water). The concentration of $\mathrm{F}^{-}$ranges from $3.4 \mathrm{mg} / \mathrm{L}$ (spring water) to $4.0 \mathrm{mg} / \mathrm{L}$ (well water). In all seven groundwater samples from this flank, the average concentrations of $\mathrm{Na}^{+}, \mathrm{K}^{+}$, $\mathrm{Ca}^{2+}$, and $\mathrm{Mg}^{2+}$ in $\mathrm{mg} / \mathrm{L}$ are 170, 37.6, 36.4, and 5.7, respectively, showing once more that the $\mathrm{Na}$-K-bearing minerals are dominant in releasing cations; however, in this case, there is also an important contribution from Ca-bearing minerals. Table 6 shows that on average, water samples from the northwestern flank show a progressive increase of $\mathrm{Na}^{+}$, $\mathrm{K}^{+}, \mathrm{HCO}_{3}{ }^{-}+\mathrm{CO}_{3}{ }^{2-}, \mathrm{SO}_{4}{ }^{2-}, \mathrm{F}^{-}$, and $\mathrm{NO}_{3}{ }^{-}$from elevation of $2567 \mathrm{~m}$ to $2084 \mathrm{~m}$, while $\mathrm{Ca}^{2+}, \mathrm{Mg}^{2+}$, and $\mathrm{Cl}^{-}$remain constant; descending further, most ions remain comparable towards the lower elevations (average: $1838 \mathrm{~m}$ ); this is attributed to shorter residence time as groundwater flows through fractures between 2084 and $1838 \mathrm{~m}$ elevations (see Section 3.1). On the western flank, on average, all ions except $\mathrm{F}^{-}$(which remains constant) increase from the upstream to the downstream. Figure 11 shows the projection of the different water samples from the northwestern and western flanks in the Piper diagram.

Table 6. Average values of major and minor ions in the water samples from different elevations on the northwestern and western flanks ( ${ }^{*}$ as $\mathrm{mg} / \mathrm{L} \mathrm{HCO}_{3}{ }^{-}$).

\begin{tabular}{|c|c|c|c|c|c|c|c|c|c|c|c|c|c|}
\hline \multirow{2}{*}{ Region } & \multirow{2}{*}{ Water Source } & \multirow{2}{*}{$\begin{array}{c}\text { Number } \\
\text { of } \\
\text { Samples }\end{array}$} & \multirow{2}{*}{$\begin{array}{c}\text { Average } \\
\text { Elevation } \\
(\mathrm{m})\end{array}$} & \multicolumn{10}{|c|}{ Average Concentrations $(\mathrm{mg} / \mathrm{L})$} \\
\hline & & & & $\mathrm{Na}^{+}$ & $\mathrm{K}^{+}$ & $\mathrm{Ca}^{2+}$ & $\mathrm{Mg}^{2+}$ & $\left(\mathrm{HCO}_{3}{ }^{-}+\mathrm{CO}_{3}^{2-}\right)^{*}$ & $\mathrm{SO}_{4}{ }^{2-}$ & $\mathrm{Cl}^{-}$ & $\mathbf{F}^{-}$ & $\mathrm{NO}_{3}{ }^{-}$ & $\mathrm{NO}_{2}{ }^{-}$ \\
\hline \multirow{3}{*}{$\begin{array}{l}\text { North-western } \\
\text { flank }\end{array}$} & \multirow{3}{*}{ Springs } & 4 & 2567 & 32.2 & 11.0 & 3.3 & 0.6 & 111 & 0.3 & 4.7 & 0.8 & 0.9 & 0.001 \\
\hline & & 15 & 2084 & 91.5 & 19.6 & 2.9 & 0.6 & 185 & 8.8 & 4.1 & 24.4 & 8.4 & 0.328 \\
\hline & & 6 & 1838 & 99.1 & 24.6 & 3.2 & 0.5 & 235 & 8.7 & 4.1 & 24.8 & 5.2 & 0.022 \\
\hline \multirow{2}{*}{ Western flank } & Spring & 1 & 2240 & 111 & 23.4 & 16.4 & 3.1 & 365 & 14.0 & 7.7 & 3.4 & 6.0 & 0.004 \\
\hline & Shallow wells & 6 & 1649 & 180 & 39.9 & 39.7 & 6.1 & 539 & 75.1 & 25.7 & 3.7 & 36.7 & 2.743 \\
\hline
\end{tabular}

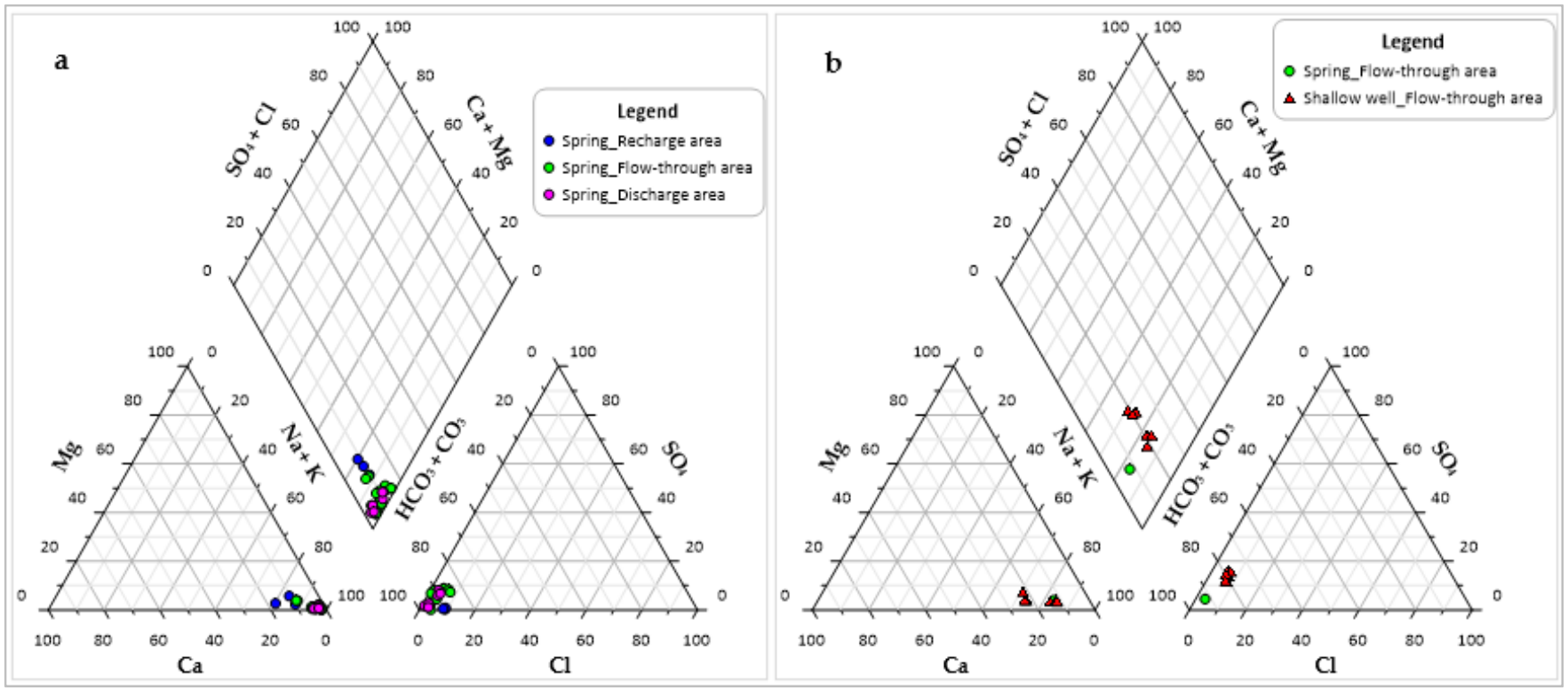

Figure 11. Piper diagrams showing different water samples taken from: (a) springs on the northwestern flank and (b) the spring and shallow wells on the western flank. 


\subsubsection{Southwestern Flank}

The concentration of $\mathrm{Na}^{+}$in groundwater ranges from $75.8 \mathrm{mg} / \mathrm{L}$ (spring water) to $425 \mathrm{mg} / \mathrm{L}$ (shallow well water), whereas the concentration of $\mathrm{HCO}_{3}{ }^{-}+\mathrm{CO}_{3}{ }^{2-}$ ranges from $209 \mathrm{mg} / \mathrm{L} \mathrm{HCO}_{3}{ }^{-}$(spring water) to $1114 \mathrm{mg} / \mathrm{L} \mathrm{HCO}_{3}{ }^{-}$(shallow well water). The concentration of $\mathrm{F}^{-}$ranges from 2.0 to $122 \mathrm{mg} / \mathrm{L}$ (both from shallow well waters). In all 71 groundwater samples from this flank, the average concentrations of $\mathrm{Na}^{+}, \mathrm{K}^{+}, \mathrm{Ca}^{2+}$, and $\mathrm{Mg}^{2+}$ in $\mathrm{mg} / \mathrm{L}$ are 221, 52.7, 19.4, and 4.4 respectively, indicating that the Na-K-bearing minerals are dominant in releasing cations in the groundwater. Table 7 shows that on average, water samples from springs show a progressive increase of all ions except $\mathrm{F}^{-}$ (which decreases) from upstream to downstream, whereas water samples from shallow wells show a progressive increase of all ions from elevation of 1631 to $1548 \mathrm{~m}$; the two shallowest wells (average well depth: $6 \mathrm{~m}$ ) at lower elevations (average: $1379 \mathrm{~m}$ ) show decreases in $\mathrm{Na}^{+}, \mathrm{K}^{+}, \mathrm{HCO}_{3}{ }^{-}+\mathrm{CO}_{3}{ }^{2-}$, and $\mathrm{F}^{-}$but increases in $\mathrm{Ca}^{2+}, \mathrm{Mg}^{2+}, \mathrm{SO}_{4}{ }^{2-}, \mathrm{Cl}$, and $\mathrm{NO}_{3}{ }^{-}$, this is attributed to the local flow system in the area (see Section 3.1). In addition, deep wells at the downstream show lower concentrations for in all ions except $\mathrm{Ca}^{2+}$ and $\mathrm{Mg}^{2+}$ (which remain constant) compared to shallow wells at intermediate elevations (average: $1548 \mathrm{~m}$ ); these are low mineralised deep circulating waters that have undergone deep infiltration in the recharge area at higher elevations through fractures and faults (see Section 3.1). Table 8 shows water samples containing unusually high concentration of $\mathrm{NO}_{3}{ }^{-}$. Two shallow wells W36 and W69 at intermediate elevations $(1561 \mathrm{~m}$ and $1513 \mathrm{~m}$, respectively) show unusually high concentrations of $\mathrm{NO}_{3}{ }^{-}(129 \mathrm{mg} / \mathrm{L}$ and $258 \mathrm{mg} / \mathrm{L}$, respectively), which largely exceed the average concentration of this anion $(37.3 \mathrm{mg} / \mathrm{L})$ at intermediate elevations (average: $1548 \mathrm{~m}$ ), as indicated in Table 7 . In addition, two shallow wells W100 and W101 at lower elevations (1385 m and $1373 \mathrm{~m}$ respectively) show unusually high concentrations of $\mathrm{NO}_{3}{ }^{-}(134 \mathrm{mg} / \mathrm{L}$ and $167 \mathrm{mg} / \mathrm{L}$ respectively) despite the fact that shorter water residence times are attributed to these wells. The unusually high $\mathrm{NO}_{3}{ }^{-}$values in these four wells are accompanied by high $\mathrm{SO}_{4}{ }^{2-}$ and $\mathrm{Cl}^{-}$values, which all together are indicative of local anthropogenic pollution [29], especially from domestic sewage. Figure 12 shows the projection of the different water samples from this flank in the Piper diagram.

Table 7. Average values of major and minor ions in the water samples from different elevations on the southwestern flank (* as $\mathrm{mg} / \mathrm{L} \mathrm{HCO}_{3}{ }^{-}$).

\begin{tabular}{|c|c|c|c|c|c|c|c|c|c|c|c|c|c|}
\hline \multirow{2}{*}{$\begin{array}{l}\text { Water } \\
\text { Source }\end{array}$} & \multirow{2}{*}{$\begin{array}{l}\text { Number of } \\
\text { Samples }\end{array}$} & \multirow{2}{*}{$\begin{array}{c}\text { Average } \\
\text { Elevation } \\
\text { (m) }\end{array}$} & \multirow{2}{*}{$\begin{array}{c}\text { Average } \\
\text { Well Depth } \\
\text { (m) }\end{array}$} & \multicolumn{10}{|c|}{ Average Concentrations (mg/L) } \\
\hline & & & & $\mathrm{Na}^{+}$ & $\mathrm{K}^{+}$ & $\mathrm{Ca}^{2+}$ & $\mathrm{Mg}^{2+}$ & $\left(\mathrm{HCO}_{3}^{-}+\mathrm{CO}_{3}^{2-}\right)^{*}$ & $\mathrm{SO}_{4}{ }^{2-}$ & $\mathrm{Cl}^{-}$ & $\mathbf{F}^{-}$ & $\mathrm{NO}_{3}^{-}$ & $\mathrm{NO}_{2}^{-}$ \\
\hline \multirow{2}{*}{ Springs } & 2 & 1921 & & 76.4 & 22.8 & 4.4 & 0.7 & 212 & 7.5 & 6.1 & 12.0 & 3.0 & 0.02 \\
\hline & 10 & 1566 & & 182 & 60.0 & 21.7 & 4.9 & 539 & 23.4 & 16.6 & 8.1 & 37.0 & 0.16 \\
\hline \multirow{3}{*}{$\begin{array}{l}\text { Shallow } \\
\text { wells }\end{array}$} & 3 & 1631 & 16 & 160 & 30.8 & 10.2 & 1.4 & 439 & 24.5 & 9.0 & 6.3 & 20.8 & 0.15 \\
\hline & 51 & 1548 & 19 & 248 & 55.9 & 18.5 & 4.0 & 672 & 34.0 & 18.3 & 15.8 & 37.3 & 0.64 \\
\hline & 2 & 1379 & 6 & 109 & 36.9 & 61.1 & 20.8 & 367 & 47.3 & 40.9 & 2.3 & 151 & 0.67 \\
\hline $\begin{array}{l}\text { Deep } \\
\text { wells }\end{array}$ & 3 & 1467 & 151 & 120 & 27.7 & 19.3 & 4.8 & 400 & 16.2 & 7.5 & 5.4 & 5.4 & 0.02 \\
\hline
\end{tabular}

Table 8. Water samples containing an unusually high concentration of $\mathrm{NO}_{3}{ }^{-}$on the southwestern flank.

\begin{tabular}{|c|c|c|c|c|c|c|c|}
\hline Town & Water Point ID & Water Source & Elevation $(\mathrm{m})$ & Well Depth (m) & $\mathrm{SO}_{4}{ }^{2-}(\mathrm{mg} / \mathrm{L})$ & $\mathrm{Cl}^{-}(\mathrm{mg} / \mathrm{L})$ & $\mathrm{NO}_{3}{ }^{-}(\mathrm{mg} / \mathrm{L})$ \\
\hline \multirow{2}{*}{ Ngaramtoni } & W36 & Shallow well & 1561 & 19 & 59.2 & 28.7 & 129 \\
\hline & W69 & Shallow well & 1513 & 19 & 88.7 & 67.0 & 258 \\
\hline \multirow{2}{*}{ Arusha } & W100 & Shallow well & 1385 & 9 & 37.0 & 34.6 & 134 \\
\hline & W101 & Shallow well & 1373 & 2 & 57.6 & 47.2 & 167 \\
\hline
\end{tabular}




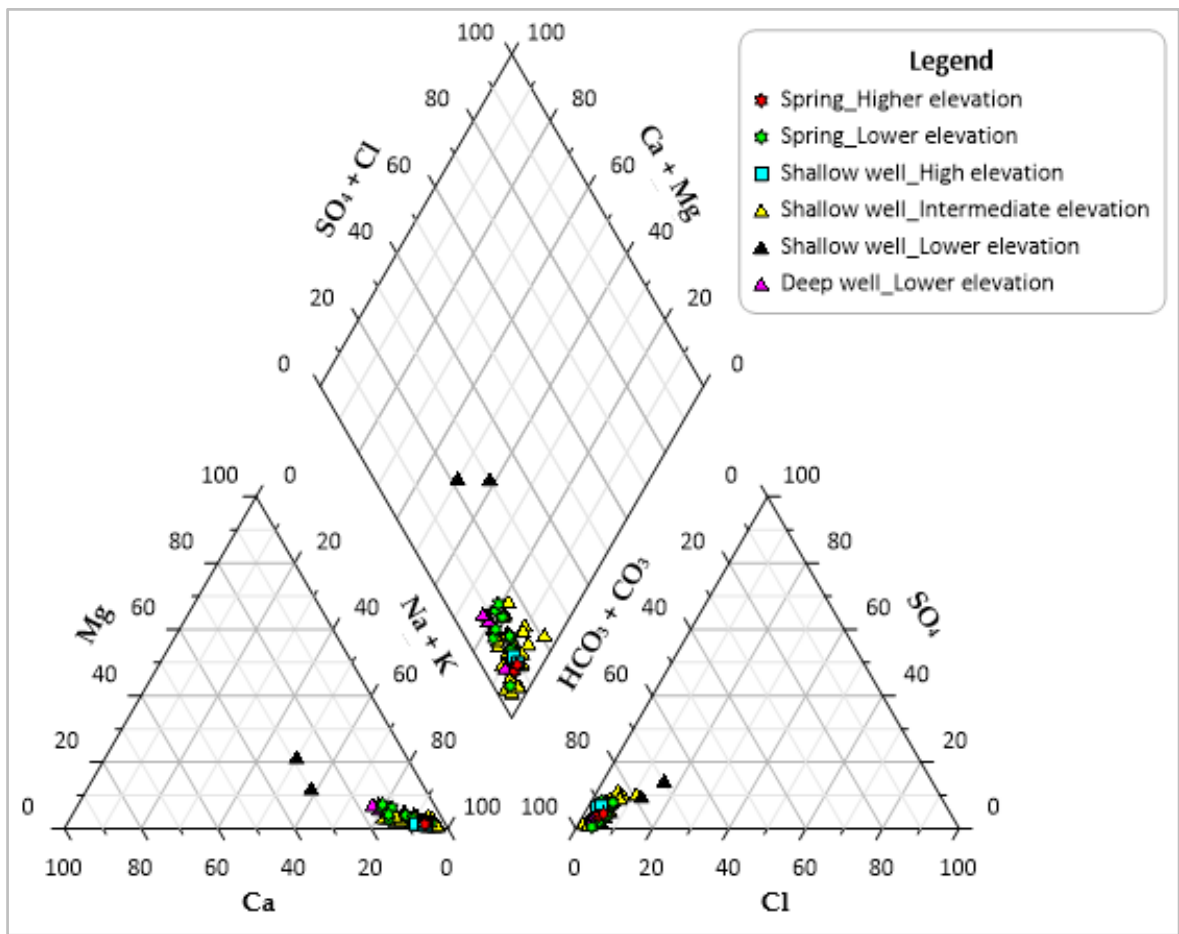

Figure 12. Piper diagram showing different water samples taken from springs, shallow wells, and deep wells on the southwestern flank.

In all the analysed water samples $(\mathrm{n}=181)$ for this study, $39 \%(\mathrm{n}=71)$ of the samples have $\mathrm{Na}^{+}$concentrations above the WHO taste-based guideline of $200 \mathrm{mg} / \mathrm{L}$ [10] (p. 227); 51 samples are from wells, 24 are from springs and all of the six surface waters, whereas $7 \%(\mathrm{n}=13)$ of samples have $\mathrm{SO}_{4}{ }^{2-}$ concentrations above the WHO taste-based guideline of $250 \mathrm{mg} / \mathrm{L}$ [10] (p. 227); eight samples are from springs from the discharge area, two are from the hydrothermal springs, and three are from surface waters (one lake, one stream, one water pond). In addition, $2 \%(\mathrm{n}=3)$ of samples have $\mathrm{Cl}^{-}$concentrations above the WHO taste-based guideline of $250 \mathrm{mg} / \mathrm{L}$ [10] (p. 223); two samples are from lakes and one is from a stream, whereas $10 \%(\mathrm{n}=19)$ of samples have $\mathrm{NO}_{3}{ }^{-}$concentrations above the WHO health-based guideline of $50 \mathrm{mg} / \mathrm{L}$ [10] (p. 196); 14 samples are from wells and five are from springs from the discharge areas. In 175 groundwater samples, 91\% $(n=160)$ of the samples have $\mathrm{F}^{-}$concentrations higher than the WHO limit $(1.5 \mathrm{mg} / \mathrm{L})$ recommended for drinking water [10] (p. 42). The $9 \%(\mathrm{n}=15)$ of the samples with $\mathrm{F}^{-}$concentrations lower than the WHO limit are mainly from springs $(n=13)$ from the recharge areas on the eastern and northwestern flanks of Mount Meru inside the Arusha National Park. Based on the Tanzanian limit (4.0 mg/L) [37] (p. 26), 79\% $(\mathrm{n}=138)$ of the samples are above the limit. All of the six surface waters have $\mathrm{F}^{-}$concentrations higher than both $\mathrm{WHO}$ and Tanzanian limits. Table 9 summarises the overview of the usable groundwater sources from the sampled inventoried groundwater points in reference to their $\mathrm{F}^{-}$concentrations. From the 122 sampled inventoried groundwater points, $93 \%(n=114)$ of the points provide usable groundwater sources for different purposes; drinking, other domestic use, irrigation, and livestock. From the 114 usable groundwater points, 59\% $(n=67)$ of the points are used to provide drinking water to the local community despite their high $\mathrm{F}^{-}$values, which exceed both $\mathrm{WHO}$ and Tanzanian limits, as most local people do not have any alternative for drinking water. Only $11 \%(n=13)$ of the usable points are not used for drinking purpose due to their high $\mathrm{F}^{-}$values, which exceed the limits of the two standards. It appears that the only way of accessing safe drinking water in the study area is to tap groundwater from the springs from the recharge areas at higher elevations on the eastern and northwestern flanks of the Mount Meru, inside the Arusha National Park, in which $\mathrm{F}^{-}$concentrations 
are lower due to lower rock weatherability and short water residence times. This has been the current practice on the ground.

Table 9. Overview of the usable groundwater sources from the sampled inventoried groundwater points in reference to their $\mathrm{F}^{-}$concentrations $\left(\mathrm{F}^{-}\right.$upper limits recommended for drinking water: $\mathrm{WHO}=1.5 \mathrm{mg} / \mathrm{L}$; Tanzanian $=4.0 \mathrm{mg} / \mathrm{L}$ ).

\begin{tabular}{|c|c|c|c|c|c|}
\hline Region & Water Source & Number of Water Points & $\begin{array}{c}\text { Range of } \mathrm{F}^{-} \text {Values } \\
(\mathrm{mg} / \mathrm{L})\end{array}$ & $\begin{array}{c}\text { Within WHO or } \\
\text { Tanzanian Standard }\end{array}$ & Drinking Purpose \\
\hline \multirow{3}{*}{$\begin{array}{l}\text { Eastern flank, inside the } \\
\text { Arusha National Park }\end{array}$} & \multirow{3}{*}{ Springs } & 10 & $0.1-1.5$ & WHO standard & Yes \\
\hline & & 3 & $1.7-3.9$ & Tanzanian standard & Yes \\
\hline & & 2 & $15-19$ & Above the standards & Yes \\
\hline \multirow{7}{*}{$\begin{array}{l}\text { Far east of the eastern } \\
\text { flank (Northern flank of } \\
\text { Ngurdoto crater) }\end{array}$} & \multirow{3}{*}{ Springs } & & & & \multirow{3}{*}{$\begin{array}{l}\text { No, used for other } \\
\text { domestic use and } \\
\text { livestock } \\
\text { Yes }\end{array}$} \\
\hline & & 1 & 2.6 & Tanzanian standard & \\
\hline & & 1 & 11 & Above the standards & \\
\hline & \multirow{4}{*}{ Wells } & 2 & $1.0-1.3$ & WHO standard & Yes \\
\hline & & 4 & $1.6-3.5$ & Tanzanian standard & Yes \\
\hline & & 4 & $4.5-8.2$ & Above the standards & Yes \\
\hline & & 3 & $31-134$ & Above the standards & Yes \\
\hline \multirow{10}{*}{ North-eastern flank } & \multirow{4}{*}{ Springs } & 2 & $4.2-4.3$ & Above the standards & \multirow{4}{*}{$\begin{array}{c}\text { Yes } \\
\text { No, used for irrigation } \\
\text { and livestock } \\
\text { Yes } \\
\text { No, used for irrigation } \\
\text { and livestock }\end{array}$} \\
\hline & & 1 & 4.3 & Above the standards & \\
\hline & & 4 & $6-13$ & Above the standards & \\
\hline & & 5 & $48-75$ & Above the standards & \\
\hline & \multirow{6}{*}{ Wells } & 1 & 3.6 & Tanzanian standard & \multirow{6}{*}{$\begin{array}{c}\text { No, used for irrigation } \\
\text { No, used for other } \\
\text { domestic use and } \\
\text { livestock } \\
\text { Yes } \\
\text { No, used for other } \\
\text { domestic use and } \\
\text { livestock } \\
\text { Yes }\end{array}$} \\
\hline & & 1 & 12 & Above the standards & \\
\hline & & & & & \\
\hline & & 2 & $14-19$ & Above the standards & \\
\hline & & 2 & $20-22$ & Above the standards & \\
\hline & & 1 & 121 & Above the standards & \\
\hline \multirow{5}{*}{ North-western flank } & \multirow{5}{*}{ Springs } & 3 & $0.4-0.8$ & WHO standard & Yes \\
\hline & & 1 & 1.7 & Tanzanian standard & Yes \\
\hline & & 5 & $18-27$ & Above the standards & Yes \\
\hline & & 1 & 28 & Above the standards & \multirow{2}{*}{$\begin{array}{c}\text { No, used for irrigation } \\
\text { Yes }\end{array}$} \\
\hline & & 1 & 48 & Above the standards & \\
\hline \multirow{2}{*}{ Western flank } & Spring & 1 & 3.4 & Tanzanian standard & Yes \\
\hline & Wells & 3 & $3.5-4.0$ & Tanzanian standard & Yes \\
\hline \multirow{10}{*}{ South-western flank } & Springs & 8 & $5.1-13.0$ & Above the standards & Yes \\
\hline & \multirow{9}{*}{ Wells } & 5 & $2.0-3.8$ & Tanzanian standard & \multirow{9}{*}{$\begin{array}{c}\text { Yes } \\
\text { Yes } \\
\text { No, used for irrigation } \\
\text { Yes } \\
\text { No, used for other } \\
\text { domestic use and } \\
\text { irrigation } \\
\text { Yes } \\
\text { Yes } \\
\text { No, used for other } \\
\text { domestic use and } \\
\text { irrigation }\end{array}$} \\
\hline & & 5 & $4.6-6.1$ & Above the standards & \\
\hline & & 1 & 6.3 & Above the standards & \\
\hline & & 8 & $6.3-8.5$ & Above the standards & \\
\hline & & 1 & 9.3 & Above the standards & \\
\hline & & & & & \\
\hline & & 15 & $9.6-17.0$ & Above the standards & \\
\hline & & 6 & $22.4-60.4$ & Above the standards & \\
\hline & & 1 & 77.9 & Above the standards & \\
\hline
\end{tabular}

\section{Temporal Variability of Fluoride Concentrations and Precipitation/Recharge Values}

Figure 13 shows the temporal variability of $\mathrm{F}^{-}$concentrations in the groundwater samples taken in September 2017 and September 2018. The time variability in $\mathrm{F}^{-}$concentrations (sampled in two different dry seasons) is more pronounced in Ngarenanyuki and Oldonyo Sambu (the driest areas) than in Ngaramtoni and Mamsa. In 29 investigated groundwater points, $93 \%(n=27)$ showed higher $\mathrm{F}^{-}$concentrations in September 2018 than in September 2017. The $\mathrm{F}^{-}$concentrations in September 2018 range from a minimum of $3.4 \mathrm{mg} / \mathrm{L}$ to a maximum of $122.4 \mathrm{mg} / \mathrm{L}$ with an average of $35.0 \mathrm{mg} / \mathrm{L}$ and a median of $15.8 \mathrm{mg} / \mathrm{L}$, while in September 2017, the values range from a minimum of $3.9 \mathrm{mg} / \mathrm{L}$ to a maximum of $41.2 \mathrm{mg} / \mathrm{L}$ with an average of $15.9 \mathrm{mg} / \mathrm{L}$ and a median of $9.8 \mathrm{mg} / \mathrm{L}$. The Mann-Whitney $U$ test showed that at the significance level $(\alpha)$ of 0.05 , the $\mathrm{F}^{-}$concentrations are not statistically significantly different. This is probably due to a small sample size $(n=29)$, the chosen level of significance, and the variability in the samples. Since this small sample size fails to detect the difference at $\alpha=0.05$, therefore, the significance level for this test was increased to 0.1 . At the significance level of 0.1 , the $\mathrm{F}^{-}$concentrations in September 2018 (mean rank = 33.64) are statistically significantly higher than in September 2017 (mean 
rank $=25.36)(\mathrm{U}=540.500, \mathrm{p}=0.062)$. The pronounced elevated $\mathrm{F}^{-}$concentrations in Ngarenanyuki and Oldonyo Sambu can be attributed to low groundwater recharge as the year 2018 was drier (annual rainfall: $680 \mathrm{~mm}$ ) than 2017 (annual rainfall: $797 \mathrm{~mm}$ ) as recorded at ASA Farm station in Ngaramtoni. Table 10 shows that the spring discharges (Q) during water sampling in April 2019 (at the end of an exceptionally dry rainy season) were slightly lower than in August 2019 (dry season), while their $\mathrm{F}^{-}$values were slightly higher; this indicates that the low spring discharge resulting from slow groundwater flow favors long water-rock interactions and hence high mineralisation of the groundwater (high EC values) with high $\mathrm{F}^{-}$concentrations.

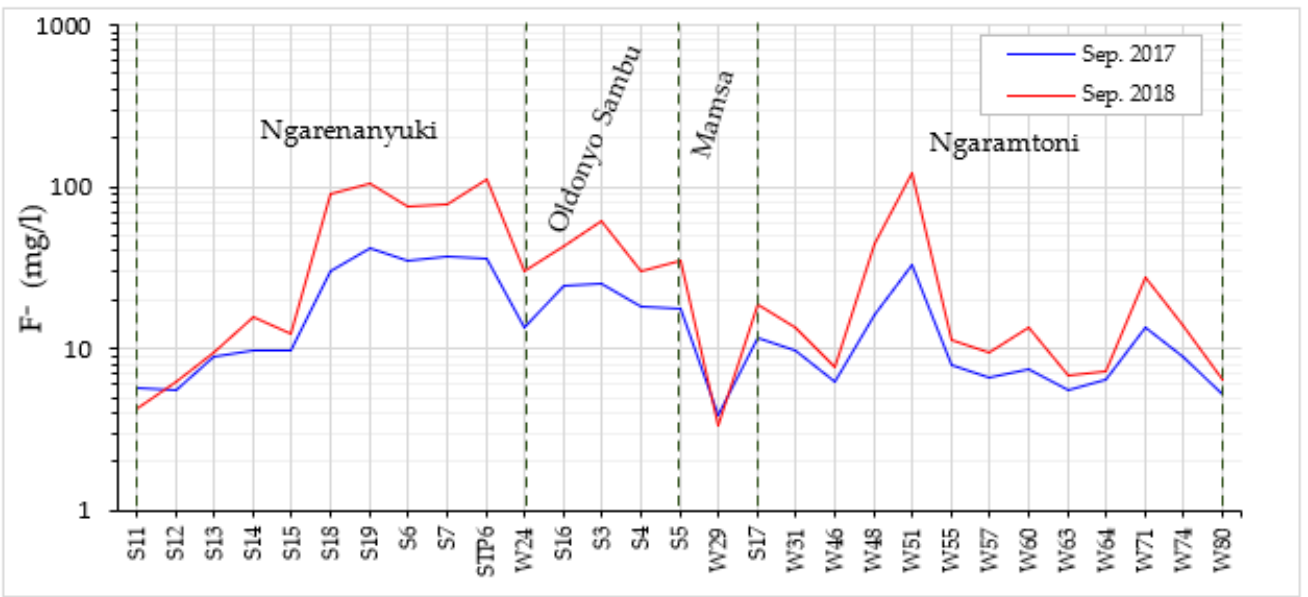

Figure 13. Temporal variability of $\mathrm{F}^{-}$concentrations in the groundwater samples taken in September 2017 and September 2018.

Table 10. Spring discharges (Q), $\mathrm{F}^{-}$concentrations, and EC for springs S3 and S5 (at Oldonyo Sambu) and S22 (at Ngaramtoni).

\begin{tabular}{ccccc}
\hline Spring ID & Date & $\mathbf{Q}\left(\mathbf{m}^{\mathbf{3}} / \mathbf{h r}\right)$ & $\mathbf{F}^{-}(\mathbf{m g} / \mathbf{L})$ & EC $\left(\boldsymbol{\mu S} / \mathbf{c m}\right.$ at $\left.2{ }^{\circ} \mathbf{C}\right)$ \\
\hline \multirow{2}{*}{ S3 } & April 2019 & 5.98 & 20.3 & 443 \\
& Aug. 2019 & 7.17 & 18.6 & 415 \\
\hline \multirow{2}{*}{ S5 } & April 2019 & 34.23 & 15.0 & 436 \\
& Aug. 2019 & 46.62 & 13.7 & 407 \\
\hline \multirow{2}{*}{ S22 } & April 2019 & 1.97 & 5.5 & 822 \\
& Aug. 2019 & 2.24 & 4.7 & 781 \\
\hline
\end{tabular}

Figure 14 shows that the spring discharges at Oldonyo Sambu (S3 and S5) start to rise after approximately a month time lag (mid-May) after the start of heavy rains at mid-April and continue to rise through the dry season until the next rainy season, indicating that the recharge area is situated at relatively large distance. The spring discharge at Ngaramtoni (S22) starts to rise immediately after the start of rainfall and declines immediately after the end of the rainy season, indicating that the spring receives local recharge. Thus, the lower $\mathrm{F}^{-}$concentration for S22, both during the dry and the rainy season, is due to shorter water-rock interactions, as is clearly demonstrated by S22's much faster response to rainfall, compared to S3 and S5. However, the high EC values of S22 compared to S3 and S5 are attributed to the influence of the mantling ash deposits. The S22 is located in the pyroclastics with subordinate nephelinitic and phonolitic lavas covered with mantling ash. Here, the area is surrounded by mantling ash deposits. Ash deposits are very loose and fine-grained; these characteristics make them highly weatherable and readily dissolve in water. The S3 and S5 are located in the Lemurge DAD, and their recharge area is located in pyroclastics with subordinate nephelinitic and phonolitic lavas. There are no ash deposits in these areas. Therefore, the lower EC values of S3 and S5 compared to S22 are attributed 
to the slow weathering of lavas. The lavas deposits are more compact and less weatherable as compared to the DADs and mantling ash deposits.

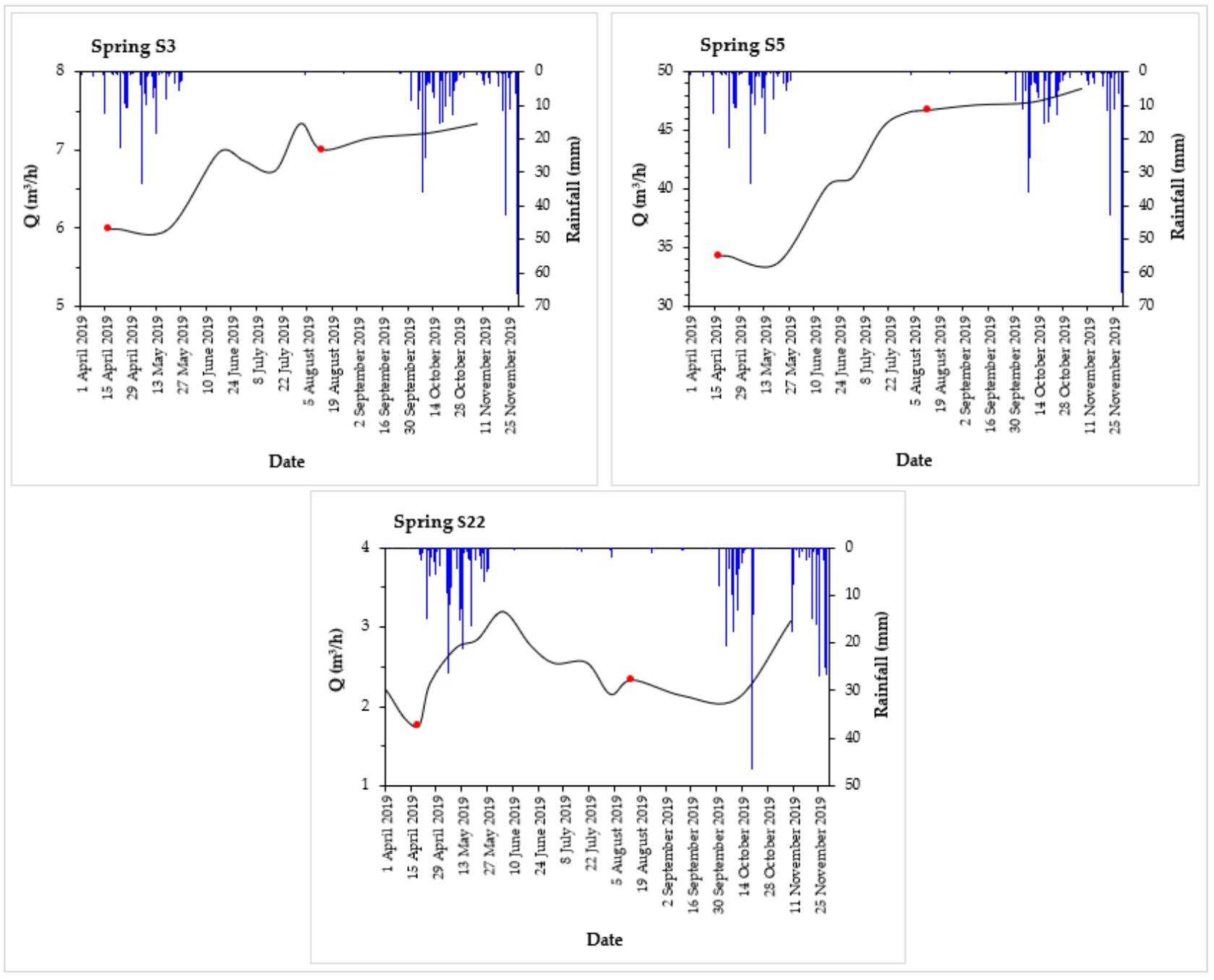

Figure 14. Spring discharge fluctuation at Oldonyo Sambu (S3 and S5) and at Ngarenanyuki (S22), and rainfall (Mamsa rain station for S3 and S5, and ASA Farm rain station for S22). Red dots indicate discharge values during water sampling.

\section{Conclusions and Recommendations}

The groundwater chemistry in the study area shows that the main groundwater type in the study area is $\mathrm{NaHCO}_{3}$ alkaline groundwater with an average $\mathrm{pH}=7.8$. The groundwater shows high variability in most of the physicochemical parameters, indicating complex hydrochemical conditions, due to the complexity of groundwater flow lines with different residence times, and passing through different geological formations of variable weatherability. Mineralisation generally increases with increasing residence times. In general, the higher springs show lower concentrations of the different hydrogeochemical parameters compared to lower springs, followed by the deep wells and lastly the shallow wells, indicating different groundwater flow systems. The two hydrothermal springs near the ash cone are highly mineralised compared to the surrounding springs; this indicates that they are originating from a deep source, suggesting the influence of volcanic emissions at depth.

Most groundwater sources analysed in this study are not suitable for human consumption due to their high $\mathrm{F}^{-}$concentrations exceeding the WHO recommended limit for drinking water $(1.5 \mathrm{mg} / \mathrm{L})$. This represents a challenge, as most people do not have any alternative for drinking water. The range of $\mathrm{F}^{-}$concentrations in springs, deep wells, 
and shallow wells in $\mathrm{mg} / \mathrm{L}$ are $0.15-301,3.8-7.8$, and 1.0-134, respectively. One of the hydrothermal springs shows the highest $\mathrm{F}^{-}$value of $301 \mathrm{mg} / \mathrm{L}$. The temporal variability in $\mathrm{F}^{-}$concentrations between different seasons is due to the impact of local groundwater recharge.

As a result of the superior quality of the low-fluoride spring water from the highaltitude recharge areas on the eastern and northwestern flanks of Mount Meru inside Arusha National Park, the current practice is to extract their water for drinking purposes and pipe it to taps for the rural communities in the lower parts of the flanks. We recommend that a detailed ecohydrological study should be carried out to ensure the sustainability of this water extraction practice. Since the low-fluoride springs are in the upstream within the Arusha National Park, their extraction possibly affects the ecology of wildlife in the downstream inside the national park. Therefore, a long-term spring discharge monitoring together with biodiversity monitoring will help to establish a sustainable water management plan for these springs. Another strategy for obtaining safe drinking water could be to use a large-scale filtering system to remove $\mathrm{F}^{-}$from the groundwater.

Author Contributions: Conceptualisation, G.B., C.S., M.K. (Matthieu Kervyn) and K.W.; Data curation, G.B.; Formal analysis, G.B.; Funding acquisition, C.S. and M.K. (Matthieu Kervyn); Investigation, G.B., J.V.R., C.S., I.T., K.F. and K.W.; Methodology, G.B., C.S. and K.W.; Project administration, C.S. and M.K. (Matthieu Kervyn); Resources, G.B., C.S., I.T., K.F., M.K. (Matthieu Kervyn) and K.W.; Software, G.B.; Supervision, C.S., M.K. (Matthieu Kervyn) and K.W.; Validation, G.B. and K.W.; Visualisation, G.B. and K.W.; Writing—original draft, G.B.; Writing-review and editing, G.B., C.S., M.K. (Mary Kisaka), I.T., K.F., M.K. (Matthieu Kervyn) and K.W. All authors have read and agreed to the published version of the manuscript.

Funding: This research was funded by the Flemish Interuniversity Council-University Development Cooperation (VLIR-UOS) in the framework of project TZ2017TEA450A105 'Optimizing the valorization of water and rock resources for improved livelihoods in the Arusha volcanic region'.

Institutional Review Board Statement: Not applicable.

Informed Consent Statement: Not applicable.

Data Availability Statement: The data presented in this study are available on request from the corresponding author.

Acknowledgments: The authors thank the Tanzania Commission for Science and Technology (COSTECH) and Tanzania National Parks Authority (TANAPA) for providing research permits. In addition, the authors thank Laura Segers and Stefanie Rombaut for their assistance during fieldworks. Thanks to Martine Leermakers and Natacha Brion (AMGC, Vrije Universiteit Brussel) for their help with chemical analysis of some water samples. Ines Tomašek acknowledges the support received from the VUB Strategic Research Program (SRP) and the Agence Nationale de la Recherche of the French government through the program "Investissements d'Avenir" (16-IDEX-0001 CAP 20-25). Karen Fontijn acknowledges support from F.R.S.-FNRS MIS grant F.4515.20. The findings and conclusions in this paper are those of the authors and do not necessarily represent the official position of VLIR-UOS.

Conflicts of Interest: The authors declare no conflict of interest.

\section{References}

1. Pavelic, P.; Giordano, M.; Bernard, N. Groundwater Availability and Use in Sub-Saharan Africa: A Review of 15 Countries; International Water Management Institute: Colombo, Sri Lanka, 2012. [CrossRef]

2. Mato, R.R.A.M. Groundwater Pollution in urban Dar es Salaam, Tanzania: Assessing Vulnerability and Protection Priorities. Ph.D. Thesis, Eindhoven University of Technology, Eindhoven, The Netherlands, 19 June 2002. [CrossRef]

3. McKenzie, M.; Mark, B.G.; Thompson, L.G.; Schotterer, U.; Lin, P.N. A hydrogeochemical survey of Kilimanjaro (Tanzania): Implications for water sources and ages. Hydrogeol. J. 2010, 18, 985-995. [CrossRef]

4. Ghiglieri, G.; Balia, R.; Oggiano, G.; Pittalis, D. Prospecting for safe (low fluoride) groundwater in the Eastern African Rift: The Arumeru District (Northern Tanzania). Hydrol. Earth Syst. Sci. 2010, 14, 1081-1091. [CrossRef]

5. Ghiglieri, G.; Pittalis, D.; Cerri, G.; Oggiano, G. Hydrogeology and hydrogeochemistry of an alkaline volcanic area: The NE Mt. Meru slope (East African Rift—Northern Tanzania). Hydrol. Earth Syst. Sci. 2012, 16, 529-541. [CrossRef] 
6. Chacha, N.; Njau, K.N.; Lugomela, G.V.; Muzuka, A.N.N. Hydrogeochemical characteristics and spatial distribution of groundwater quality in Arusha well fields, Northern Tanzania. Appl. Water Sci. 2018, 8, 118. [CrossRef]

7. Makoba, E.; Muzuka, A.N.N. Water quality and hydrogeochemical characteristics of groundwater around Mt. Meru, Northern Tanzania. Appl. Water Sci. 2019, 9, 120. [CrossRef]

8. Mtoni, Y.; Mjemah, I.C.; Bakundukize, C.; Van Camp, M.; Martens, K.; Walraevens, K. Saltwater intrusion and nitrate pollution in the coastal aquifer of Dar es Salaam, Tanzania. Environ. Earth Sci. 2013, 70, 1091-1111. [CrossRef]

9. Malago, J.; Makoba, E.; Muzuka, A.N.N. Fluoride levels in surface and groundwater in Africa: A review. Am. J. Water Sci. Eng. 2017, 3, 1-17. [CrossRef]

10. World Health Organization (WHO). Guidelines for Drinking-Water Quality: Fourth Edition Incorporating the First Addendum; World Health Organization: Geneva, Switzerland, 2017. Available online: https://apps.who.int/iris/bitstream/handle/10665/254637 /9789241549950-eng.pdf?sequence=1 (accessed on 12 February 2020).

11. Nanyaro, J.T.; Aswathanarayana, U.; Mungure, J.S.; Lahermo, P.W. A geochemical model for the abnormal fluoride concentrations in waters in parts of northern Tanzania. J. Afr. Earth Sci. 1984, 2, 129-140. [CrossRef]

12. Rango, T.; Bianchini, G.; Beccaluva, L.; Tassinari, R. Geochemistry and water quality assessment of central Main Ethiopian Rift natural waters with emphasis on source and occurrence of fluoride and arsenic. J. Afr. Earth Sci. 2010, 57, 479-491. [CrossRef]

13. Haji, M.; Wang, D.; Li, L.; Qin, D.; Guo, Y. Geochemical evolution of fluoride and implication for $\mathrm{F}^{-}$enrichment in groundwater: Example from the Bilate River Basin of Southern Main Ethiopian Rift. Water 2018, 10, 1799. [CrossRef]

14. Gaciri, S.; Davies, T. The occurrence and geochemistry of fluoride in some natural waters of Kenya. J. Hydrol. 1993, 143, 395-412. [CrossRef]

15. Coetsiers, M.; Kilonzo, F.; Walraevens, K. Hydrochemistry and source of high fluoride in groundwater of the Nairobi area, Kenya / Hydrochimie et origine des fortes concentrations en fluorure dans l'eau souterraine de la région de Nairobi, au Kenya. Hydrol. Sci. J. 2008, 53, 1230-1240. [CrossRef]

16. Gevera, P.; Mouri, H. Natural occurrence of potentially harmful fluoride contamination in groundwater: An example from Nakuru County, the Kenyan Rift Valley. Environ. Earth Sci. 2018, 77, 365. [CrossRef]

17. Dibal, H.U.; Schoeneich, K.; Garba, I.; Lar, U.A.; Bala, E.A. Occurrence of fluoride in the drinking waters of Langtang area, north central Nigeria. Health 2012, 4, 1116-1126. [CrossRef]

18. Kilham, P.; Hecky, R.E. Fluoride: Geochemical and ecological significance in East African waters and sediments. Limnol. Oceanogr. 1973, 18, 932-956. [CrossRef]

19. Kitalika, A.J.; Machunda, R.L.; Komakech, H.C.; Njau, K.N. Fluoride variations in rivers on the slopes of Mount Meru in Tanzania. J. Chem. 2018, 2018, 7140902. [CrossRef]

20. Delcamp, A.; Kervyn, M.; Benbakkar, M.; Kwelwa, S.; Peter, D. Large volcanic landslide and debris avalanche deposit at Meru, Tanzania. Landslides 2017, 14, 833-847. [CrossRef]

21. NASA/METI/AIST/Japan Spacesystems, and U.S./Japan ASTER Science Team, 2011. ASTER Global Digital Elevation Model Version 2. NASA EOSDIS Land Processes DAAC. Available online: https:/ / doi.org/10.5067/ASTER/ASTGTM.002 (accessed on 10 December 2017).

22. Tanzania National Bureau of Statistics. 2012 Population and Housing Census: Population Distribution by Administrative Areas; Tanzania National Bureau of Statistics: Dar es Salaam, Tanzania, 2013. Available online: https://www.nbs.go.tz/nbs/takwimu/ census2012/Census_General_Report.zip (accessed on 26 November 2020).

23. Wilkinson, P.; Downie, C.; Cattermole, P.J.; Mitchell, J.G. Arusha, Geological Survey of Tanzania, Quarter Degree Sheet 55.1983. Available online: https://library.wur.nl/WebQuery/file/isric/fulltext/isricu_i33425_001.pdf (accessed on 15 June 2017).

24. Scoon, R.N. Arusha national park (Mount Meru). In Geology of National Parks of Central/Southern Kenya and Northern Tanzania; Springer: Cham, Switzerland, 2018; pp. 141-154. [CrossRef]

25. Central Intelligence Agency (CIA). The World Factbook Book. Africa: Tanzania. Available online: https://www.cia.gov/theworld-factbook/countries/tanzania/locator-map (accessed on 15 June 2018).

26. Wikipedia. Arusha Region. Available online: https://en.wikipedia.org/wiki/Arusha_Region (accessed on 15 June 2018).

27. Kisaka, M.; Fontijn, K.; Shemsanga, C.; Tomašek, I.; Gaduputi, S.; Debaille, V.; Delcamp, A.; Kervyn, M. The late Quaternary eruptive history of Meru Volcano, Northern Tanzania. J. Volcanol. Geotherm. Res. 2021, 417, 107314. [CrossRef]

28. American Public Health Association; American Water Works Association; Water Environment Federation. Standard Methods for the Examination of Water and Wastewater, 23rd ed.; American Public Health Association: Washington, DC, USA, 2017.

29. Walraevens, K.; Bakundukize, C.; Mtoni, Y.E.; Van Camp, M. Understanding the hydrogeochemical evolution of groundwater in Precambrian basement aquifers: A case study of Bugesera region in Burundi. J. Geochem. Explor. 2018, 188, 24-42. [CrossRef]

30. Piper, A.M. A graphical interpretation of water analysis. Trans. Am. Geophys. Union. 1944, 25, 914-928. [CrossRef]

31. Tóth, J. A theoretical analysis of groundwater flow in small drainage basins. J. Geophys. Res. 1963, 68, 4795-4812. [CrossRef]

32. Tóth, J. Groundwater as a geologic agent: An overview of the causes, processes, and manifestations. Hydrogeol. J. 1999, 7, 1-14. [CrossRef]

33. Sawyer, G.M.; Carn, S.A.; Tsanev, V.I.; Oppenheimer, C.; Burton, M. Investigation into magma degassing at Nyiragongo volcano, Democratic Republic of the Congo. Geochem. Geophys. Geosyst. 2008, 9, Q02017. [CrossRef] 
34. Jasim, A.; Hemmings, B.; Mayer, K.; Scheu, B. Groundwater flow and volcanic unrest. In Volcanic Unrest. Advances in Volcanology; Gottsmann, J., Neuberg, J., Scheu, B., Eds.; Springer: Cham, Switzerland, 2018; pp. 83-99. [CrossRef]

35. Fischer, T.P.; Arellano, S.; Carn, S.; Aiuppa, A.; Galle, B.; Allard, P.; Lopez, T.; Shinohara, H.; Kelly, P.; Werner, C.; et al. The emissions of $\mathrm{CO}_{2}$ and other volatiles from the world's subaerial volcanoes. Sci. Rep. 2019, 9, 18716. [CrossRef] [PubMed]

36. Bakundukize, C.; Mtoni, Y.E.; Van Camp, M.; Walraevens, K. Occurrences of evaporitic salts in Bugesera region (Burundi) and relation to hydrogeochemical evolution of groundwater. Environ. Earth Sci. 2018, 77, 223. [CrossRef]

37. Tanzania Bureau of Standards (TBS). TZS 789:2008: Drinking (Potable) Water-Specification; Tanzania Bureau of Standards: Dar es Salaam, Tanzania, 2008. 